\title{
3. EFFECTS OF RELATIVE SEA-LEVEL CHANGES ON THE DIAGENESIS OF EOCENE SEDIMENT: NEW JERSEY SLOPE AND COASTAL PLAIN ${ }^{1}$
}

\author{
Cecilia M.G. McHugh ${ }^{2,3}$
}

\begin{abstract}
Eocene lithology recovered by the Ocean Drilling Program Legs 150 and 150X was studied to evaluate the effects of relative sea-level changes on the diagenesis of the sediment. Island Beach, Atlantic City, and Cape May boreholes were drilled on the coastal plain during Leg 150X, and Sites 902-904 and 906 were drilled on the continental slope (400-1200 m of water depth) during Leg 150. The shallow- to deep-water transect provides an opportunity to examine the diagenetic transformations of the sediment with increasing distance from the shoreline. Numerous episodes of diagenesis (with formation of micrite, sparry calcite, dolomite, and silica cements) typical of the near-shore, near-surface environment occurred in the coastal plain sediment. In contrast, less nucleation of crystallites, coarser crystal forms, and diagenesis below the bacterial sulfate reduction zone are characteristic of the upper slope Sites. Diagenesis is patchy at the middle slope, where some microfossils still maintain their primary cementation.

Sediment adjacent to three main Eocene slope unconformities records physical and chemical changes that differ from those of the sediment within the sequences. The most extensive alterations occur in upper Eocene sediment beneath the contact with the upper Oligocene. This contact, marked by a seismic reflection that can be traced throughout the slope to the shelf and correlated to a sequence boundary, represents a major transition from an Eocene pelagic carbonate-dominated margin to an Oligocene hemipelagic siliciclastic-dominated margin. Lithologically, this transition is manifested in upper Eocene sediment by a decrease in the calcium carbonate and opal content and by an increase in detrital minerals. Diagenetic fluids transformed the unconformable surface of upper Eocene biosiliceous chalks into a mosaic of euhedral to subhedral dolomite rhombs that petrographic analyses suggest were deposited by highly saturated fluids at low temperatures. The upper Oligocene silty clays above contain abundant quartz, illite, kaolinite, and brown glauconites that indicate terrigenous sediment transport and reworking.

More episodes of diagenesis, abundant former fluid migration routes, which suggest increased pore-fluid activity, and sediment reworking are associated with the two other Eocene unconformable surfaces. Energy dispersive X-ray analyses of former fluid pathways and the matrix of the sediment above and below these unconformable surfaces suggest that the sources for the fluids were local. These unconformities that separate the uppermost middle Eocene and the lower/middle Eocene have also been documented at other slope Sites and at the coastal plain, and appear to be widespread throughout the continental margin.
\end{abstract}

\section{INTRODUCTION}

Relative sea-level change and sediment burial are two of the most significant agents for sediment transformation on a passive margin (Margins Steering Committee Members, 1993). The diagenetic fluids that alter the sediment are to a great extent controlled by processes associated with these events. However, the diagenetic history of passive margin sediment in response to changes in sea level remains poorly understood. Ocean Drilling Program (ODP) Legs 150 and $150 X$ were drilled on the New Jersey continental margin to evaluate the effects of glacioeustatic changes on continental margin sedimentation (Mountain, Miller, Blum, et al., 1994). During Leg 150X, Island Beach, Atlantic City, and Cape May boreholes were drilled on the coastal plain and during Leg 150, Sites 902-904 and 906 were drilled on the continental slope (400-1200 m of water depth; Fig. 1). Although the major focus of the New Jersey sea-level transect was on the Oligocene to Holocene depositional sequences, drilling also penetrated Eocene sediment. Unconformities occur on the margin that document relative sea-level lowerings during the Eocene on the coastal plain and slope (Olsson and Wise, 1987; Poag and Low, 1987; Miller et al., 1990; Miller et al., 1996b; Browning et al., Chapters 17 and 18 , this volume). An extensive array of seismic lines permitted the correlation of seismic reflections from the slope to the shelf and

${ }^{1}$ Miller, K.G., and Snyder, S.W. (Eds.), 1997. Proc. ODP, Sci. Results, 150X: College Station, TX (Ocean Drilling Program).

${ }^{2}$ Queens College, City University of New York, 65-30 Kissena Blvd., Flushing, NY 11367, U.S.A.cmmqc@qcvaxa.acc.qc.edu

Lamont-Doherty Earth Observatory of Columbia University, Palisades, NY 10964 , U.S.A.cecilia@lamont.ldeo.columbia.edu to sequence boundaries, and document a glacioeustatic lowering at the Eocene/Oligocene boundary. Other Eocene unconformities have been described for the slope that correlate to onshore coastal plain boreholes and appear to be widespread throughout the New Jersey continental margin (Olsson and Wise, 1987; Poag and Low, 1987; Miller et al., 1990; Miller, et al., 1994; Aubry et al., 1996; Browning et al., Chapters 17 and 18, this volume).

During the Eocene, the New Jersey continental margin was a ramp-type margin dominated by pelagic sedimentation (Poag, Watts, et al, 1987; Mountain, Miller, Blum, et al., 1994). Calcareous and siliceous oozes were deposited at sedimentary rates that in the bathyal environment reached $3 \mathrm{~cm} / 1$ k.y. (Mountain, Miller, Blum, et al., 1994). Normal marine sedimentation was disrupted in the late Eocene by an impact event(s) (Poag, Watts, et al., 1987; Thein, 1987; Glass, 1989; Poag et al., 1992, 1994; Poag and Aubry, 1995; Mountain, Miller, Blum, et al., 1994; McHugh et al., 1996b; Glass and McHugh, 1996). The ejecta associated with this event have been found at Site 903 (Glass and McHugh, 1996), at Site 904 (Mountain, Miller, Blum, et al., 1994; McHugh et al., 1996b), and at Deep Sea Drilling Project (DSDP) Site 612 (Poag, Watts, et al., 1987; Thein, 1987; Glass, 1989; Poag and Aubry, 1995). The ejecta found at the slope sites are correlative to the Exmore Boulder Bed in the Chesapeake Bay (Poag et al., 1992; Poag and Aubry, 1995) and are of the same age as sediment with mixed biostratigraphic markers recovered at the Atlantic City and Island Beach boreholes (Miller, Mountain, Blum, et al., 1994; Miller, Chapter 1, this volume).

The shallow- to deep-water transect drilled by ODP Legs 150 and $150 \mathrm{X}$ provides an opportunity to evaluate the diagenetic transformations that occurred in the sediment with progressive distance from the shoreline. The sediment adjacent to sequence boundaries and to other 


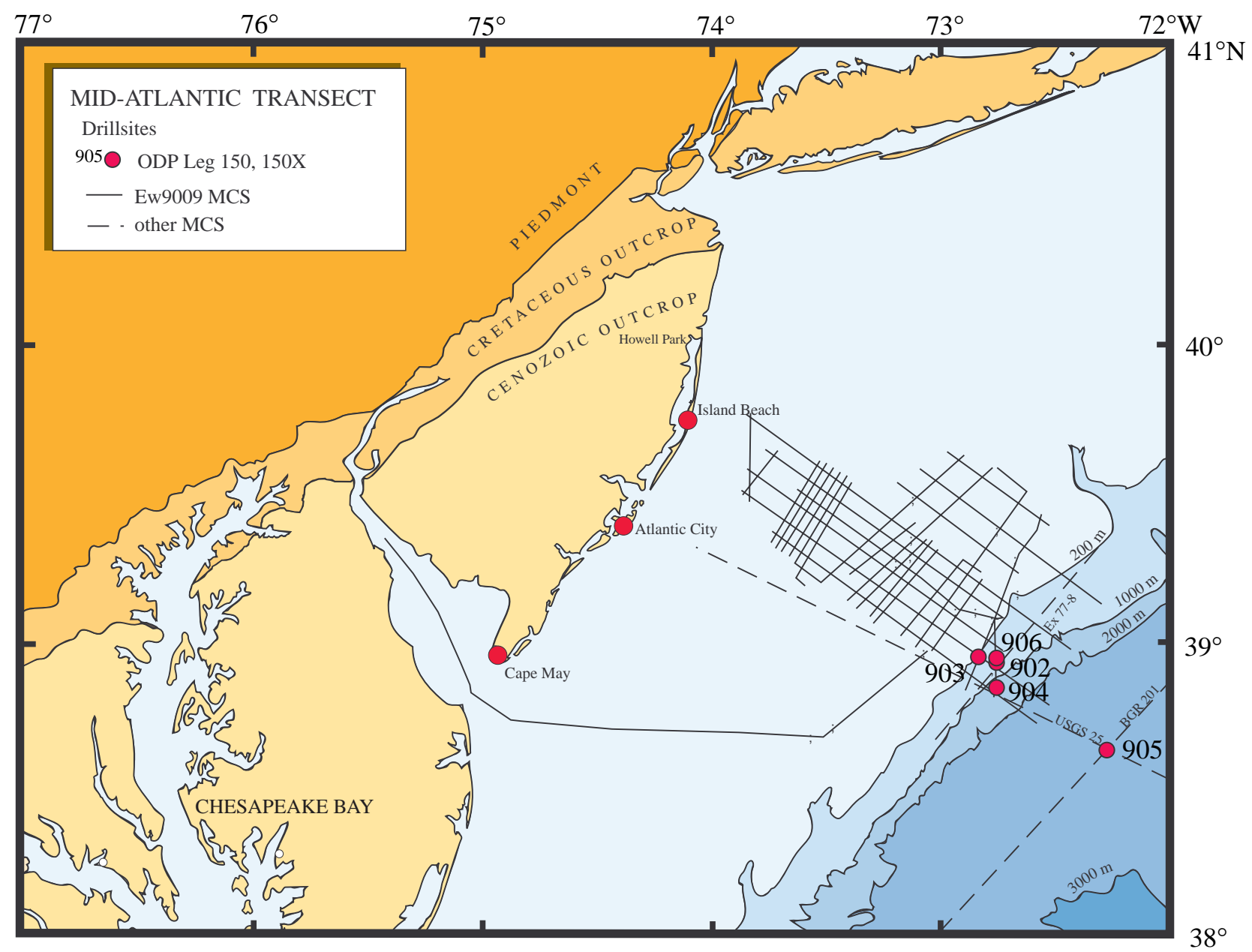

Figure 1. Location of Legs 150 and 150X drill sites on the New Jersey slope, rise, and coastal plain. Multichannel seismic lines permitted the correlation of seismic reflections between the slope and shelf.

unconformable surfaces records the physical and chemical changes that occurred in response to the changing character of the fluids. The gradual Eocene paleoslopes permit us to study the alteration of the sediment with minor influence from gravitationally induced fluid motion and to more clearly isolate the effects of sea-level fluctuations. The major objectives of this study are (1) to contrast and compare the diagenetic changes between the paleoshelf and paleoslope sediments, (2) to characterize the diagenesis of the slope sediment at unconformable surfaces, and (3) to contrast and compare the diagenesis associated with an impact event to that of normal marine sedimentation. Results presented in this study are based on petrographic observations, qualitative energy dispersive X-ray (EDX), scanning electron/energy dispersive X-ray (SEM/EDX), X-ray diffraction (XRD), and carbonate and opal analyses.

\section{METHODS}

Petrographic thin sections were stained with Alizarin red-S and potassium ferricyanide to distinguish calcite from dolomite, and dolomite from iron-rich dolomite and ferroan carbonates. Total calcium carbonate and opal analyses were conducted at Lamont-Doherty Earth Observatory (LDEO). The total calcium carbonate was obtained using a Coulometric 5011 carbonate-carbon analyzer and fol- lowed the same procedure as used on the JOIDES Resolution. Carbonate content is expressed as weight percentage $\mathrm{CaCO}_{3}$, assuming all the carbonate was present as calcite. Opal concentrations were determined by extracting biogenic silica from the samples with an alkaline solution and then measuring the dissolved silicon concentration in the extract by molybdate-blue spectrophotometry, as specified by Mortlock and Froelich (1989).

Qualitative EDX analyses were conducted on a Cameca Camebax at LDEO. The analyses were conducted at 100 counts vertical for 10 counting seconds at $15 \mathrm{kV}$, accelerating voltage at $\sim 2500 \mathrm{cps}$. SEM/ EDX analyses were conducted at LDEO on a Cambridge Stereoscan $250 \mathrm{mk} 2$ and a Kevex 8000 microanalyzer. The analyses were run for 30 counting seconds at $2000 \mathrm{cps}$ and at an accelerating voltage of 20 $\mathrm{kV}$. The spectrum for both types of analyses (EDX and SEM/EDX) was self-scaled, with the highest peak displayed at $100 \%$ vertical scale so that all other peak heights are directly proportional (i.e., small peaks are relative to the highest on the vertical scale). All peaks were $k \alpha$ peaks, so they can be directly compared.

The bulk mineral composition of upper Oligocene and upper Eocene slope sediment was studied by XRD analyses. The mineralogy was determined using the Phillips X-ray diffractometer with CuKå radiation ( $\mathrm{Ni}$ filter). Instrument conditions were as follows: 40 $\mathrm{Kv}, 40 \mathrm{~mA}$, goniometer scan from $2^{\circ}$ to $60^{\circ}$, step size $0.02^{\circ}$, count time $0.2 \mathrm{~s}, 0.1 \% \mathrm{~s}$. Bulk sediments were crushed and mounted in ran- 
dom orientation in aluminum sample holders. The relative distribution of the identified minerals was determined from the intensity of their main diffraction peak. The minerals studied for bulk mineralogy and their respective main diffraction peaks were quartz (3.34 $\AA$ ), feldspar (3.18 to $3.25 \AA$ ), amphibole (8.4 to $8.5 \AA$ ), calcite (3.03 $\AA$ ), dolomite $(2.89 \AA)$, siderite $(2.8 \AA)$, pyrite $(2.71 \AA)$, and graphite $(1.67$ $\AA$ ). Opal-A was identified by a very broad peak around $4 \AA$, and opalCT by a peak near $4.1 \AA$ (Kastner, 1981).

\section{EOCENE STRATA: COASTAL PLAIN}

During Leg 150X, Eocene sediment was recovered from three locations on the coastal plain: Island Beach, Atlantic City, and Cape May. Described below are the lower to middle Eocene from Island Beach and the middle and upper Eocene from Atlantic City. Eocene strata also outcrop on the coastal plain, and a few samples recovered from Howell Park, New Jersey, are also described.

\section{Island Beach}

\section{Petrography of Lower Eocene Sediment}

The Eocene section at Island Beach spans from 1075 to $697 \mathrm{ft}$ (327.7-212.5 m) and contains lower, middle, and upper Eocene sediment (Miller, et al., 1994). Samples were studied from the lower to middle Eocene (999-826 ft [304.3-251.8 m]). The sediment recovered indicates an overall shallowing upward sequence with paleodepths that ranged from 100 to $200 \mathrm{~m}$ for the lower Eocene, 50 to 150 $\mathrm{m}$ for the middle Eocene, and 50 to $100 \mathrm{~m}$ for the upper Eocene (Miller, et al., 1994; Browning, et al., Chapters 17 and 18, this volume). Island Beach sediment provides the shallowest end-member of the shallow- to deep-water transect. Several disconformities occur in the Eocene at this borehole (Browning, et al., Chapters 17 and 18, this volume). Future studies will concentrate on these surfaces.

At Island Beach, lower Eocene sediment from plankton Zones P7-P8 and NP12 (Miller, et al., 1994) consists of greenish gray silty clays and clays. The sediment is generally darker gray than the slope sediment as a result of higher clay and detrital mineral content. Coastal plain sediment is also coarser grained than the slope, and silty clays are commonly interbedded with sandy clays.

Silica diagenesis has led to the dissolution of the opaline silica tests of diatoms and/or radiolarians (Fig. 2; Table 1). The tests have been replaced by opal-CT and/or chert, and only their ghosts remain. The term "ghosts" refers to the dissolution of the skeletal parts with preservation of the tests shapes that have at times been replaced by another mineral (Tucker and Wright, 1992). Intervals of more extensive silica diagenesis are recognized by the occurrence of porcellanites that are characterized by fluid pathways extending over $10 \%-$ $40 \%$ of the matrix (i.e., $895 \mathrm{ft}$ [272.9 m], $925 \mathrm{ft}$ [282.3 m], and 960.5 $\mathrm{ft}[292.9 \mathrm{~m}])$. Former fluid migration routes are noted by dark-stained rims. Microfractures filled with silica occur within fluid pathways and are oriented parallel, oblique, and orthogonal to bedding (Fig. 2). Microfractures at Island Beach are always mineralized. The origin of these features (former fluid pathways and microfractures) is related to the diagenetic dewatering that accompanies the transition of biogenic opal A to opal-CT and chert, with progressive burial (Jones and Segnit, 1972; Weaver and Wise, 1972). This diagenetic reaction involves the expulsion of substantial amounts of water of crystallization that leads to a subsequent volume reduction with formation of microfractures. Lower Eocene porcellanites have been well documented for the North Atlantic (Thein and von Rad, 1987; Wilkens et al., 1987; Riech and von Rad, 1979; McHugh et al., 1993). The front that marks the diagenetic transition from biogenic oozes to porcellanites has been identified and correlated throughout most of the western North Atlantic as the seismic reflection $\mathrm{A}^{\mathrm{c}}$ (Tucholke and Mountain, 1979; Poag, Watts, et al., 1987).
Coastal plain porcellanites contain $10 \%-20 \% \mathrm{CaCO}_{3}$ (Table 1); in contrast, deep-water porcellanites contain $35 \%-65 \% \mathrm{CaCO}_{3}$ and are technically calcareous porcellanites. Porcellanites in the coastal plain are characterized by an abundance of silt- to sand-sized detrital quartz (i.e., $40 \%$ of the sample at $933 \mathrm{ft}$ [284.5 m] and at $958.2 \mathrm{ft}[292.1 \mathrm{~m}]$ ) and glauconite (i.e., $20 \%$ of the sample at $895 \mathrm{ft}$ [272.9 m]). Detrital quartz is predominantly angular, but some rounded quartz also occurs. Quartz-rich intervals are interbedded with clay rich and foraminiferal-poor sediment (Fig. 2). Glauconite is an abundant mineral at the coastal plain. At some intervals (i.e., $826 \mathrm{ft}[251.8 \mathrm{~m}]$ ) glauconite is green, yellow, and brown, which suggests different episodes of diagenesis and/or transport. Brown glauconites are associated with sediment reworking (Pekar et al., Chapter 15, this volume). Detrital silt-sized feldspar (plagioclase and potassium) and mica (biotite and muscovite) also occur in the coastal plain samples.

Lower to middle Eocene foraminiferal tests are generally abundant, with well-preserved forms. Although the foraminiferal test shapes are well-preserved, few foraminiferal tests maintain their primary cementation and the majority have undergone several episodes of diagenesis (Fig. 2). Because of the complexity of the fabric and mineralogy of foraminiferal tests, the term primary cementation is used to describe the unaltered foraminiferal skeleton (Bathurst, 1975). The preservation of primary cementation in the foraminiferal tests is recognized by the occurrence of the pseudo-uniaxial cross between cross polars (Bathurst, 1975). Primary calcium carbonate has been replaced by micrite and sparry calcite, and foraminiferal tests are commonly filled with micrite and finely crystalline sparry calcite that has, at some intervals, been replaced by dolomite and ferroan carbonates (i.e., $826 \mathrm{ft}[251.8 \mathrm{~m}], 945 \mathrm{ft}[288.1 \mathrm{~m}]$, and $960.5 \mathrm{ft}$ [292.9 m]). The occurrence of finely crystalline sparry calcite indicates more nucleation of crystallites and suggests active pore fluid circulation. Foraminiferal ghosts, noted by red rims as a result of staining with Alizarin red-S, predominate at most intervals. Foraminiferal tests are also commonly filled with opal-CT or chert. These observations suggest that diagenetic transformations have been numerous and have occurred at different rates within the same intervals.

\section{Atlantic City \\ Petrography of Middle and Upper Eocene}

The Eocene at Atlantic City spans from the base of the borehole at $1452-1181 \mathrm{ft}(442.7-360 \mathrm{~m})$ and contains middle to upper Eocene sediment (Zones P12-14 and P15-17; Miller, Chapter 1, this volume; Miller, et al., 1994). Benthic foraminiferal assemblages indicate that the sediment was deposited in an outer neritic environment with paleodepths of 100-200 m (Miller, et al., 1994). Therefore, during the Eocene, this location was slightly deeper than Island Beach.

Samples were studied from the middle and upper Eocene (1438$1302 \mathrm{ft}$ [438.4-397 m]). A disconformity occurs between the upper and middle Eocene at $1352 \mathrm{ft}(412.2 \mathrm{~m})$; however, nannofossil biostratigraphy indicates that the middle/upper Eocene disconformity could be as low as $1390 \mathrm{ft}$ (423.8 m; Mountain, Miller, Blum, et al., 1994). The problem is that the interval between 1352 and $1390 \mathrm{ft}$ (412.2 and $423.8 \mathrm{~m})$ contains a mixed layer of reworked biostratigraphic markers which makes the positioning of the unconformity less certain (Miller, Chapter 1, this volume). The interval correlates with the Exmore Boulder Bed in Chesapeake Bay of Poag et al. (1992) and Poag and Aubry (1995). Lithologically, the mixed interval is composed of greenish gray silty clays and sandy silty clays with abundant glauconite. The sediment above is dark brownish gray silty clay. The interval is also characterized by an increase in $\mathrm{CaCO}_{3}$ from $\sim 5 \%$ to $\sim 13 \%$, reaching a maximum content of $26.51 \%$ at $1365 \mathrm{ft}$ (416.2 m; Table 2).

Reworking is most evident in the mixed interval at $1354 \mathrm{ft}$ (412.8 m) where abundant fluid pathways are delineated by dark-stained micrite (Plate 1). A cluster of isotropic mineral fragments occurs within 

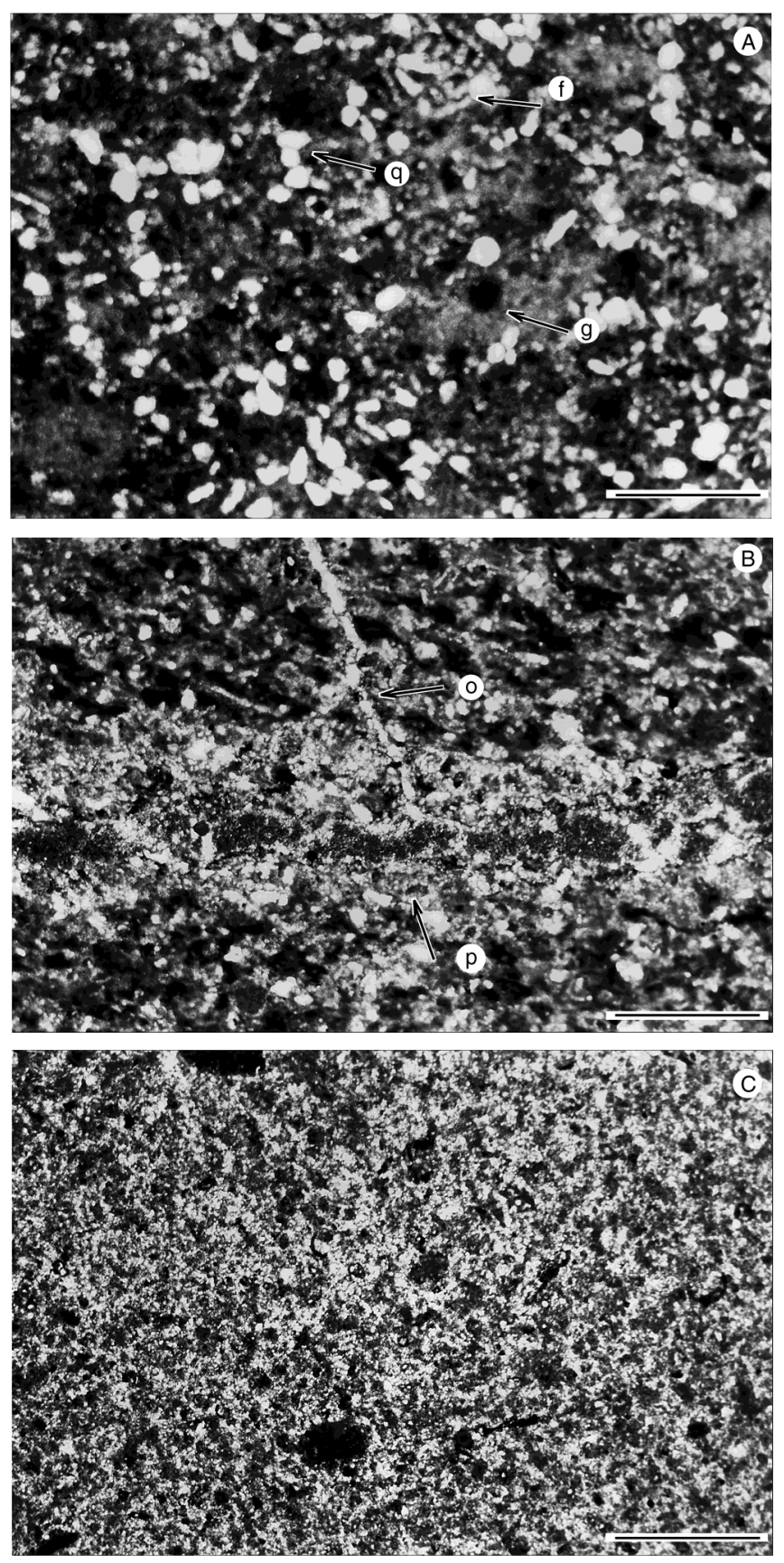

Figure 2. Thin sections of silica diagenesis at Island Beach. A. Tests of opaline silica ( $\mathrm{g}$ ) have been dissolved and replaced by opal-CT (cross-nicols). The matrix contains abundant quartz $(\mathrm{q})$, altered foraminifers ( $\mathrm{f}$ ), and is stained by former fluid pathways $(960.5 \mathrm{ft} ; 32 \mathrm{~m}$; bar $=1 \mathrm{~mm})$. B. Parallel (p) and oblique (o) silica-filled microfractures within former fluid pathways (cross-nicols; bar $=1 \mathrm{~mm}$; $933.8 \mathrm{ft} ; 31 \mathrm{~m}$ ). C. The lower Eocene at Island Beach is characterized by intervals of quartz-rich and clay-rich sediment. Clay-rich layer at $944 \mathrm{ft}(31 \mathrm{~m}$; bar $=1 \mathrm{~mm}$; cross-nicols $)$.

a broad zone of former fluid pathways (Plate 1). Other evidence of reworking are intraclasts composed of finely crystalline mineral aggregates that are commonly surrounded by dark-stained fluid pathways (Plate 1). Qualitative EDX analyses of the matrix reveal that $\mathrm{Si}$ is a major component, $\mathrm{Al}$ is moderate, and $\mathrm{Mg}, \mathrm{Ca}$, and $\mathrm{K}$ are minor. $\mathrm{An}$ indication that diagenesis has been patchy at this interval is that other matrix EDX measurements show $\mathrm{Si}$ and $\mathrm{Ca}$ to be major components, $\mathrm{Al}$ moderate, and $\mathrm{Mg}, \mathrm{K}$, and $\mathrm{Fe}$ minor.

The foraminiferal tests have been transformed to sparite and are partially and completely filled with opal and some pyrite. The foraminiferal tests are not well preserved, broken forms are common, and ghosts (recognized by their red rims) are abundant. In some instances, a cluster of broken and altered foraminifers is rimmed by fluid pathways (Plate 1). Glauconite grains have undergone extensive diagenesis and are replaced by silica (Plate 1). Glauconites also contain Al, $\mathrm{Mg}, \mathrm{K}$, and $\mathrm{Fe}$ but in lesser abundance. Most glauconite grains are rimmed by fluid pathways and have a dark diagenetic halo around them. Small $(10-50 \mu \mathrm{m})$ quartz and feldspar grains occur scattered through the sample.

Petrographic observations of samples from 1351 and $1365 \mathrm{ft}$ (411.9 and $416.2 \mathrm{~m}$ ) reveal an abundance of glauconite constituting $40 \%$ of the sediment (Table 2). Glauconite grains are sand-sized, green, gray (20\%) as a result of their diagenetic transformation to silica, or replaced by opaque stains. Their composition is dominantly $\mathrm{Si}$ and $\mathrm{Al}$ with smaller amounts of $\mathrm{K}, \mathrm{Mg}$, and $\mathrm{Fe}$.

Middle Eocene sediment below $1431 \mathrm{ft}$ (436.3 m; Miller, Chapter 1 , this volume) changes to light brownish gray clayey chalks and is more like the Eocene sediment found at the slope. Below this contact, the $\mathrm{CaCO}_{3}$ nearly doubles to $59.64 \%$ and foraminifers constitute $\sim 50 \%$ of the total sample. Several episodes of diagenesis are documented in the foraminiferal tests, which generally have wellpreserved forms (Table 2). Foraminiferal tests are altered to sparite, completely or partially filled with sparry calcite, and replaced by iron carbonates and dolomite. Some foraminiferal tests are filled with opal. Episodes of diagenesis and/or transport are also revealed by the green, yellow, and brown glauconite grains that occur sparsely through the sediment.

\section{Howell Park, New Jersey Outcrop}

The Eocene porcellanites that are now exposed on coastal plain terrestrial outcrops were initially deposited in a neritic environment with less than $150 \mathrm{~m}$ of water depth (Miller et al., 1990). The porcellanite layer is upper lower to lower middle Eocene and correlates to the subsurface coastal plain and slope sites (Miller et al., 1990). Photomicrographs of the sediment show abundant glauconite $50 \%$ of the sample) and foraminiferal tests infilled and/or replaced by glauconite. The matrix is dense (matrix porosity is $\sim 10 \%$ ), cryptocrystalline, and SEM micrographs show that it has been recrystallized into an amorphous cement (McHugh, 1993). Except for a few well-developed opal-CT lepispheres, the samples do not have a well-defined crystal morphology. The primary component of the rock is silica. Minor elements present are $\mathrm{Mg}, \mathrm{Al}, \mathrm{P}, \mathrm{S}, \mathrm{K}, \mathrm{Ca}$, and $\mathrm{Fe}$. The exposed porcellanite-chert layer has only traces of calcium carbonate $(0.142 \%)$

\section{EOCENE STRATA: SLOPE}

Middle and upper Eocene sediment was studied in the slope. The slope sites are described below in order of increasing distance from the shore to evaluate the diagenetic changes of the sediment. Sites 903 and 906, located $\sim 140$ and $\sim 141 \mathrm{~km}$ away from the New Jersey coast, respectively, were drilled on the upper continental slope at 440 $\mathrm{m}$ and $923 \mathrm{~m}$ of water depth, respectively. Site 906 , although closer to the shore than Site $902(\sim 145 \mathrm{~km})$, is deeper because it was drilled on the thalweg of modern Berkeley Canyon. Site 902 was drilled on the middle continental slope at $811 \mathrm{~m}$ of water depth. Site 904 on the lower middle continental slope, is the furthest from the shore $(\sim 150$ $\mathrm{km}$ ), and the deepest of all sites, at $1123 \mathrm{~m}$ of water depth. Sediment was deposited in the upper bathyal (Hole 903C), middle bathyal (Holes 902D and 906A), and lower bathyal (Hole 904A) environments (Katz and Miller, 1996). 
Table 1. Island Beach petrology.

\begin{tabular}{|c|c|c|c|c|c|c|c|c|c|c|c|c|c|c|}
\hline $\begin{array}{l}\text { Depth } \\
(\mathrm{ft} / \mathrm{m})\end{array}$ & Age & $\begin{array}{l}\mathrm{CaCO}_{3} \\
(\mathrm{wt} \%)\end{array}$ & $\begin{array}{c}\text { Opal } \\
(\mathrm{wt} \%)\end{array}$ & Sand & Silt & Clay & $\mathrm{Dolo} / \mathrm{Fe}$ & $\begin{array}{c}\text { Diatoms/ } \\
\text { radiolarians }\end{array}$ & Foram & Glauco & Opaques & Quartz & Matrix & Description \\
\hline $827 / 252.1$ & m. Eo. & 41.45 & 11.38 & 5 & 25 & 70 & 10 & 0 & 25 & 10 & 15 & 20 & 20 & $\begin{array}{l}\text { Fp15\%; glauco: green, yell, brn; forams: poorly prsrvd, to sparite, filled w/ pyrite and } \\
\text { dolo, no primary cementation. }\end{array}$ \\
\hline $895 / 272.9$ & 1. Eo. & NM & NM & 20 & 20 & 60 & 0 & Ghosts?-10 & 20 & 20 & 10 & 30 & 10 & $\begin{array}{l}\text { Forams: ghosts recognized by red rims some to sparite, poor prsrvd; no fp; qtz ang; patchy } \\
\text { matrix: micrite, opal; glauco: green, brn. }\end{array}$ \\
\hline $899.95 / 274.4$ & 1. Eo. & 9.57 & 7.92 & 0 & 25 & 75 & 0 & Ghosts?-10 & 5 & 5 & 5 & 5 & 70 & $\mathrm{Fp} 40 \%$; frcts $10 \%$, some orth; forams: few, to opal; qtz ang. \\
\hline $900.1 / 274.4$ & 1. Eo. & $\mathrm{NM}$ & NM & 0 & 25 & 75 & & Ghosts?-10 & 10 & 5 & 5 & 10 & 60 & $\begin{array}{l}\text { Patches of micrite and opal on matrix; forams: ghosts (red rims), to opal; rads/diat: ghosts? } \\
\text { glauco: green, brn; gtz ang; fp patches. }\end{array}$ \\
\hline $925.8 / 282.3$ & 1. Eo. & 10.68 & 6.67 & 0 & 25 & 75 & 0 & Ghosts?-10 & 10 & 2 & 10 & 8 & 60 & $\begin{array}{l}\mathrm{Fp} 15 \% \text {; frcts } 10 \% \text {, oblique, orth, rimmed by fluids; glauco: green, yell, brown; forams: } \\
\text { ghosts to opal. }\end{array}$ \\
\hline $925.8 / 282.3$ & 1. Eo. & NM & NM & 10 & 20 & 70 & 0 & Ghosts?-10 & 20 & 15 & 10 & 30 & 15 & $\begin{array}{l}\text { Fp 40\%, frcts: } 25 \% \text { : rimmed by calc, filled w/silica, ortho, obliq, wide; glauco: green, yell, } \\
\text { brn; forams: red rims, to opal. }\end{array}$ \\
\hline 933/284.5 & 1. Eo. & NM & NM & 20 & 20 & 60 & 0 & Ghosts-10 & 20 & 15 & 10 & 35 & 10 & $\begin{array}{l}\text { Glauco: green; qtz: ang, round; forams: ghosts red rims, to opal, fragments; no fp or frcts; } \\
\text { patches in matrix, intraclasts? }\end{array}$ \\
\hline $933.8 / 284.7$ & 1. Eo. & NM & NM & 20 & 20 & 60 & $<<1$ & Ghosts?-10 & 20 & 10 & 5 & 40 & 15 & $\begin{array}{l}\text { Glauco: green; qtz: ang, round; forams: ghosts red rims, to opal, well prsrvd. forms; broad } \\
\text { fp 20\%; intraclasts? }\end{array}$ \\
\hline $942 / 287.2$ & 1. Eo. & NM & NM & 10 & 20 & 70 & 0 & Ghosts?-10 & 10 & 10 & 5 & 15 & 50 & $\begin{array}{l}\text { Forams: ghosts, red rims, to opal; glauco: green; qtz ang; broad fp } 40 \% \text {; frcts: oblique, } \\
\text { ortho, filled w/ silica, } 20 \% \text {. }\end{array}$ \\
\hline $944.2 / 287.9$ & 1. Eo. & NM & NM & & 25 & 75 & 5 & Ghosts-10 & 10 & 5 & 5 & 5 & 60 & Forams: ghosts, red rims, to opal, sparite rplcd by dolo; matrix prssrvd, silica, micrite; \\
\hline $944.3 / 287.9$ & 1. Eo. & NM & NM & 10 & 25 & 65 & 5 & Ghosts-10 & 10 & 5 & 5 & 15 & 50 & $\begin{array}{l}\text { Forams: ghosts, red rims, to opal; glauco: green; qtz ang; fp over matrix; frcts: obliq, filled } \\
\text { w/ silica, } 10 \% \text {. }\end{array}$ \\
\hline $945 / 288.1$ & 1. Eo. & 17.28 & 15.12 & 10 & 25 & 65 & 5 & Ghosts-10 & 15 & 5 & 10 & 25 & 35 & $\begin{array}{l}\text { Fp 30\%, no frcts; qtz, dolo, pyrite concentrated in fp; forams: to sparite sparite to dolo, } \\
\text { poorly prsrvd; glauco: green. }\end{array}$ \\
\hline $948.5 / 289.2$ & 1. Eo. & NM & NM & 10 & 25 & 65 & 0 & Ghosts-10 & 20 & 10 & 5 & 30 & 25 & $\begin{array}{l}\text { Forams: well prsrvd, to sparite, ghosts, red rims, to opal; glauco green; qtz ang. fp broad } \\
\text { over matrix; detrital mica; }\end{array}$ \\
\hline 950/289.6 & 1. Eo. & NM & NM & 15 & 25 & 60 & 0 & Ghosts-10 & 20 & 10 & 5 & 30 & 25 & $\begin{array}{l}\text { Forams: well prssvd, to sparite, ghosts, red rims, to opal; glauco green; qtz ang; fp broad } \\
\text { over matrix; frcts filled w/silica 5\%; mica. }\end{array}$ \\
\hline $953 / 290.5$ & 1. Eo. & NM & NM & 10 & 25 & 65 & 0 & Ghosts-10 & 10 & 10 & 10 & 20 & 40 & Forams: all ghosts, to opal; qtz ang; mica; fp broad over matrix; frcts filled w/silica. \\
\hline $954 / 290.9$ & 1. Eo. & N & NM & 10 & 25 & 65 & 2 & Ghosts-10 & 13 & 5 & 5 & 10 & 55 & $\begin{array}{l}\text { Forams: ghosts, to sparite, replcd by dolo, to opal; qtz ang, round; mica; fp broad over } \\
\text { mtrx; frcts: obliq, parallel, ortho; filled w/silica, } 10 \% \text {. }\end{array}$ \\
\hline $956.8 / 291.7$ & 1. Eo. & NM & NM & 10 & 25 & 60 & 0 & Ghosts-10 & 25 & 10 & 5 & 20 & 30 & $\begin{array}{l}\text { Forams: well prsrvd, to sparite, ghosts, to opal, some primary cement; fp broad over } \\
\text { matrix: gtz ang, round, mica; glauco: green, vell: intraclasts; no frcts. }\end{array}$ \\
\hline $957.3 / 291.9$ & 1. Eo. & NM & NM & 10 & 30 & 60 & 0 & Ghosts-10 & 25 & 10 & 5 & 40 & 10 & $\begin{array}{l}\text { Forams: well prsrvd, to sparite, ghosts, to opal, some primary cement; fp broad over } \\
\text { matrix; qtz ang, round; mica; glauco: green, yell; intraclasts; no frctrs. }\end{array}$ \\
\hline 958/292.1 & 1. Eo. & NM & NM & 10 & 30 & 60 & 0 & Ghosts-10 & 25 & 10 & 5 & 40 & 10 & $\begin{array}{l}\text { Forams: well prsrvd, to sparite, ghosts, to opal, some primary cement; fp broad over } \\
\text { matrix; qtz ang, round; mica; glauco: green, yell; intraclasts; no frctrs. }\end{array}$ \\
\hline $958.2 / 292.1$ & 1. Eo. & 14.13 & 50.39 & 10 & 30 & 60 & 0 & Ghosts-10 & 25 & 10 & 5 & 40 & 10 & $\begin{array}{l}\text { Forams: well prsrvd, to sparite, ghosts, to opal, some primary cement; fp broad over } \\
\text { matrix; qtz ang, round; mica; glauco: green, yell; intraclasts; no frctrs. }\end{array}$ \\
\hline $959.5 / 292.5$ & 1. Eo. & NM & NM & 10 & 30 & 60 & 0 & Ghosts-10 & 25 & 10 & 5 & 40 & 10 & $\begin{array}{l}\text { Forams: well prsrvd, to sparite, ghosts, to opal, some primary cement; fp broad over } \\
\text { matrix; qtz ang, round; mica; glauco: green, yell; intraclasts; no fretrs. }\end{array}$ \\
\hline $960.6 / 292.9$ & 1. Eo. & 21.64 & 12.33 & 0 & 30 & 70 & 2 & Ghosts-10 & 15 & 8 & 5 & 20 & 40 & $\begin{array}{l}\text { Forams: well prsrvd, to sparite, ghosts, to opal, some primary cement, dolo; fp broad over } \\
\text { matrix; qtz ang, round; mica; glauco: green, yell; intraclasts; no frctrs. }\end{array}$ \\
\hline $961 / 293$ & 1. Eo. & NM & NM & 0 & 30 & 70 & 2 & Ghosts-10 & 15 & 8 & 5 & 20 & 40 & $\begin{array}{l}\text { Forams: well prsrvd, to sparite, ghosts, to opal, some primary cement, dolo; fp broad over } \\
\text { matrix; qtz ang, round; mica; glauco: green, yell; intraclasts; no frctrs. }\end{array}$ \\
\hline $961.5 / 293.1$ & 1. Eo. & NM & NM & 0 & 30 & 70 & 5 & Ghosts-10 & 15 & 10 & 5 & 2 & 35 & $\begin{array}{l}\text { Forams: well prsrvd, to sparite, ghosts, to opal, some primary cement, dolo; fp broad over } \\
\text { matrix; qtz ang, round; mica; glauco: green, yell; intraclasts; no frctrs. }\end{array}$ \\
\hline $965 / 294.2$ & 1. Eo. & NM & NM & 0 & 30 & 70 & 2 & Ghosts-10 & 15 & 8 & 5 & 20 & 40 & $\begin{array}{l}\text { Forams: well prsrvd, to sparite, ghosts, to opal, some primary cement, dolo; fp broad over } \\
\text { matrix; qtz ang, round; mica; glauco: green, yell; intraclasts; no frctrs. }\end{array}$ \\
\hline $965.1 / 294.2$ & 1. Eo. & NM & NM & 0 & 30 & 70 & 2 & Ghosts-10 & 15 & 8 & 5 & 20 & 30 & $\begin{array}{l}\text { Forams: well prsrvd, to sparite, ghosts, to opal, some primary cement, dolo; fp broad over } \\
\text { matrix; qtz ang, round; mica; glauco: green, yell; intraclasts; no frctrs. }\end{array}$ \\
\hline 993.9/303 & 1. Eo. & 16.37 & 9.84 & 0 & 30 & 70 & 1 & 0 & 10 & 0 & 5 & 20 & 65 & $\begin{array}{l}\text { Forams: well prsrvd, to sparite, ghosts, to opal, some primary cement, dolo; fp broad over } \\
\text { matrix; qtz ang, round; mica; glauco: green, yell; intraclasts; no frctrs. }\end{array}$ \\
\hline 993.9/303 & 1. Eo. & NM & NM & 0 & 30 & 70 & 1 & 0 & 10 & 14 & 5 & 15 & 65 & $\begin{array}{l}\text { Forams: well prsrvd, to sparite, ghosts, to opal, some primary cement, dolo; fp broad over } \\
\text { matrix; qtz ang, round; mica; glauco: green, yell; intraclasts; no frctrs. }\end{array}$ \\
\hline $999 / 304.6$ & 1. Eo. & 10.74 & 5.08 & 0 & 25 & 75 & 0 & 0 & 10 & 10 & 5 & 15 & 60 & $\begin{array}{l}\text { Forams: well prsrvd, to sparite, ghosts, to opal; fp broad over matrix; qtz ang, round; mica, } \\
\text { kspar; glauco: green, yell; frctrs: parallel. }\end{array}$ \\
\hline
\end{tabular}

Notes: Dolo/Fe $=$ dolomite/iron carbonates, Foram $=$ foraminifers, and Glauco $=$ glauconite. e. Eo. $=$ early Eocene, 1. Eo.$=$ late Eocene. $\mathrm{NM}=$ no measurements obtained. Yell $=$ yellow, brn $=$ brown, prsrvd $=$ preserved, $\mathrm{w} /=$ with, $\mathrm{fp}=$ fluid pathways, ang $=$ angular, frcts $=$ fractures, ortho $=$ orthogonal, calc $=$ calcite, obliq $=$ oblique, frgmnts $=$ fragments, rplcd $=$ replaced, $\mathrm{kspar}=$ potassium feldspar, and qtz $=$ quartz. Sand, silt, and clay are the grain sizes of the thin section
and total $100 \%$; dolo/fe, diatoms/radiolarians, foram, glauco, opaque, quartz, and matrix $=100 \%$ of thin section. The calcium carbonate is expressed as wt $\% \mathrm{CaCO}_{3}$, assuming all the carbonate present in the sample was calcite $($ see "Methods" section, this chapter) 
Table 2. Atlantic City petrology.

\begin{tabular}{|c|c|c|c|c|c|c|c|c|c|c|c|c|c|}
\hline $\begin{array}{l}\text { Depth } \\
(\mathrm{ft} / \mathrm{m})\end{array}$ & Age & $\begin{array}{c}\mathrm{CaCO}_{3} \\
(\mathrm{wt} \%)\end{array}$ & $\begin{array}{c}\text { Opal } \\
\text { (wt\%) }\end{array}$ & Sand & Silt & Clay & Dolo $/ \mathrm{Fe}$ & Foram & Glauco & Opaques & Quartz & Matrix & Description \\
\hline $1302 / 397$ & e. Eocene & 5.59 & 3.94 & 5 & 25 & 70 & 0 & 5 & 5 & 15 & 15 & 60 & $\begin{array}{l}\text { Fp } 20 \% \text {; frctrs: parallel to bed, partly filled w/ } \\
\text { opal; plag, mica; }(<<1 \%) \text {. }\end{array}$ \\
\hline $1324 / 403.7$ & e. Eocene & 13.13 & 3.46 & 5 & 25 & 70 & 0 & 5 & 5 & 15 & 20 & 55 & $\begin{array}{l}\text { Fp } 20 \% \text {; frctrs parallel to bed, partly filled w/ } \\
\text { opal. }\end{array}$ \\
\hline $1326 / 404.3$ & e. Eocene & 12.76 & 4.2 & 5 & 25 & 65 & 0 & 10 & 15 & 10 & 15 & 50 & $\begin{array}{l}\text { Glauco: green, gray, replaced by silica, pyrite; } \\
\text { fp } 40 \% \text { of matrix, dark stained; frctrs } 2 \% \\
\text { parallel to bed. }\end{array}$ \\
\hline $1351 / 411.9$ & e. Eocene & 16.68 & 4.47 & 10 & 25 & 65 & 0 & 10 & 40 & 5 & 5 & 40 & $\begin{array}{l}\text { Glauco: green, gray, replaced by silica, sand- } \\
\text { size fp } 50 \% \text { of matrix. }\end{array}$ \\
\hline $1354 / 412.8$ & e. Eocene & 13.54 & 4 & 5 & 25 & 70 & 2 & 15 & 15 & 10 & 10 & 48 & $\begin{array}{l}\text { Fp } 60 \% \text { of matrix; qtz, kspar; glauco: green, } \\
\text { gray, altered to silica, pyrite; forams: } \\
\text { fragmented, to sparite, opal; patchy } \\
\text { diagenesis. }\end{array}$ \\
\hline $1365 / 416.2$ & e. Eocene & 26.51 & 3.69 & 10 & 25 & 65 & 0 & 25 & 30 & 10 & 10 & 25 & $\begin{array}{l}\text { Fp } 40 \% \text {; forams: filled w/opal and pyrite, not } \\
\text { well prsrvd (mostly ghosts), some to spar, } \\
\text { glauco: green, gray, altered to silica. }\end{array}$ \\
\hline $1390 / 423.8$ & mid. Eocene & NM & NM & 10 & 25 & 65 & 0 & 10 & 25 & 10 & 20 & 35 & $\begin{array}{l}\text { Glauco: green; forams: to opaques and } \\
\text { microsparite, ghosts; qtz ang, round; mica. }\end{array}$ \\
\hline $1419 / 432.6$ & mid. Eocene & NM & NM & 0 & 25 & 75 & 1 & 50 & 1 & 10 & 10 & 28 & $\begin{array}{l}\text { Forams: most ghosts, detrital mica and plag, } \\
\text { fp 10\%. }\end{array}$ \\
\hline $1438 / 438.4$ & mid. Eocene & 59.64 & 14.79 & 0 & 25 & 75 & 1 & 50 & 5 & 5 & 5 & 34 & $\begin{array}{l}\text { Forams: well prsrvd, to sparite, filled w/opal } \\
\text { and dolo; fp 15\%. }\end{array}$ \\
\hline
\end{tabular}

Notes: Dolo $/ \mathrm{Fe}=$ dolomite/iron carbonates, Foram $=$ foraminifers, and Glauco $=$ glauconite. $\mathrm{e} .=$ early, mid. $=$ middle. $\mathrm{NM}=$ no measurements obtained. Yell $=$ yellow, brn $=$ brown, prsrvd $=$ preserved, $\mathrm{w} /=$ with, $\mathrm{fp}=$ fluid pathways, ang $=$ angular, frcts $=$ fractures, $\mathrm{kspar}=$ potassium feldspar, plag= plagioclase, $\mathrm{qtz}=\mathrm{quartz}$. Sand, silt, and clay are the grain sizes of the thin section and total $100 \%$; dolo/fe, forams, glauco, opaques, quartz, and matrix $=100 \%$ of thin section, values are estimated. The calcium carbonate is expressed as wt $\% \mathrm{CaCO}_{3}$, assuming all the carbonate present in the sample was calcite (see "Methods" section, this chapter).

Two unconformities have been described for the Eocene (Mountain, Miller, Blum, et al., 1994; Aubry, et al., 1996). One separates the lower/middle Eocene and has been documented at Site 904, and the other occurs within uppermost middle Eocene at Sites 903 and 904 (Mountain, Miller, Blum, et al., 1994; Aubry et al., 1996). A third major unconformity separating the upper Eocene from the upper Oligocene has been recognized at all slope Sites (Mountain, Miller, Blum, et al., 1994; Aubry et al., 1996). Seismic Reflection o1, that marks the unconformable surface, has been correlated with a global $\delta^{18} \mathrm{O}$ increase in regional cooling (Miller et al., 1996b) and represents a sequence boundary. This unconformity coincides with a significant change in the sediment depositional regime of the margin from carbonate-dominated pelagic during the Eocene to hemipelagic siliciclastic sediment during the Oligocene (Mountain, Miller, Blum, et al., 1994). Sediment was sampled within sequences, adjacent to the unconformities, and above the impact ejecta at slope Sites 903 and 904.

\section{Site 903}

\section{Petrography}

The Eocene at Hole $903 \mathrm{C}$ is $86 \mathrm{~m}$ thick and extends from middle Eocene Zone NP16 to upper Eocene Zone NP19-20 (Mountain, Miller, Blum, et al., 1994). The sediments are light greenish gray biosiliceous chalks containing foraminifers and clay (Mountain, Miller, Blum, et al., 1994). There are some differences between the Eocene sediment deposited at Hole $903 \mathrm{C}$ and the sediment deposited in the coastal plain. Compared to the coastal plain sediment (10\%-20\% $\mathrm{CaCO}_{3}$ ), the calcium carbonate content of the chalks at Hole $903 \mathrm{C}$ is higher (35\%-65\%; Fig. 3; Table 3). Generally, foraminifers are less abundant than in the coastal plain, constituting $15 \%-20 \%$ of the sediment (Fig. 4; Table 3). However, at some intervals foraminifers are more numerous at Site 903 , making up to $50 \%$ of the total sample (i.e., $1130.6 \mathrm{mbsf}$ ). Dolomite and iron carbonates are also more abundant at Site 903 than at the coastal plain, and occur in all the studied samples. Ferroan carbonates commonly fill the foraminiferal tests and they are also observed in the matrix. Ferroan carbonate crystals can be fairly large, up to $100 \mu \mathrm{m}$ (Fig. 4).

Petrographic observations and XRD analyses (at 1068, 1096, and $1112 \mathrm{~m}$ ) indicate that detrital quartz is a minor $(<5 \%)$ component of the sediment except at the interval associated with the impact ejecta (see section below). Quartz occurs in the upper $43 \mathrm{~m}$ of the Eocene section and is rare in the rest of the sediment. These observations suggest that deposition of terrigenous material was minor and occurred mostly during the late Eocene. Benthic foraminiferal assemblages also indicate minor downslope transport to Site 903 during the Eocene (Mountain, Miller, Blum, et al., 1994). Glauconite occurs in the same intervals as quartz (the upper $43 \mathrm{~m}$ ) and also constitutes a small component $(<5 \%)$ of the sediment. Quartz and glauconite are less abundant at Site 903 than at the coastal plain, where their abundance is commonly $10 \%-15 \%$ of the sediment. Opaque minerals, including pyrite, occur throughout the Eocene section, averaging $10 \%$ of the sediment.

Opal content of the sediment ranges from $10 \%$ to $37 \%$. The opal content decreases from the middle Eocene to the upper Eocene (Fig. 3 ). The same trend is observed for calcium carbonate. Generally, there is a good correlation between a decrease in the opal content and an increase in the calcium carbonate of the sediment and viceversa (Fig. 3).

Silica diagenesis is evident in the matrix by patchy zones of opalCT. Opal-CT also completely or partially fills the tests of some foraminifers. Ghosts of probable diatoms or radiolarians are noted by their forms, which have been completely replaced by opal-CT. Former fluid migration routes, which are presumably derived from the silica diagenetic reaction, become progressively more abundant downhole. Physical properties measurements show a sharp increase in bulk density of $0.25 \mathrm{~g} / \mathrm{cm}^{3}$, accompanied by a decrease in water content and porosity at $1110 \mathrm{mbsf}$ (Mountain, Miller, Blum, et al., 1994). These changes in physical properties can be correlated to the abundance of fluid pathways observed in the thin sections. Above 1110 mbsf, fluid pathways extend over $10 \%$ of the matrix, at 1110 mbsf over $75 \%$, and, deeper than 1100 mbsf fluid pathways cover $20 \%-30 \%$ of the sample. The gradual increase (except at $1110 \mathrm{mbsf}$ ) in fluid migration routes with depth is consistent with the progression of silica diagenesis as a result of burial. Microfractures occur within fluid pathways in diverse orientations: parallel, oblique, and orthogonal to bedding. In contrast to the coastal plain, microfractures are more abundant and less often mineralized (Fig. 4).

\section{Unconformities}

Two unconformities occur at Site 903 associated with the Eocene. The youngest separates the upper Eocene (Zones NP19-20) biosili- 
Table 2 (continued).

\begin{tabular}{ccc}
\hline $\begin{array}{c}\text { Depth } \\
(\mathrm{ft} / \mathrm{m})\end{array}$ & \multicolumn{1}{c}{ Age } & \multicolumn{1}{c}{ Hand sample } \\
\hline $1302 / 397$ & e. Eocene & Silty clay some sand \\
$1324 / 403.7$ & e. Eocene & Silty clay some sand, dark brownish gray \\
$1326 / 404.3$ & e. Eocene & Silty clay some sand, dark greenish gray \\
$1351 / 411.9$ & e. Eocene & Silty clay some sand, dark greenish gray \\
$1354 / 412.8$ & e. Eocene & Silty clay, dark greenish gray \\
& & \\
$1365 / 416.2$ & e. Eocene & Silty clay some sand, dark greenish gray \\
& & \\
$1390 / 423.8$ & mid. Eocene & \\
$1419 / 432.6$ & mid. Eocene & \\
$1438 / 438.4$ & mid. Eocene & Clayey chalk-buff \\
&
\end{tabular}

ceous chalks, from the upper Oligocene (Zone NP23) glauconitic sandy siltstones (Mountain, Miller, Blum, et al., 1994). Extensive diagenesis is noted in the biosiliceous chalks beneath the unconformable surface with the dark brown glauconitic sand above. At 1064.2 mbsf, the sediment consists of an idiotopic mosaic of euhedral to subhedral dolomite rhombs with local intercrystalline patches of dolomicrite and clay (Plate 2). The matrix is composed predominantly of $\mathrm{Si}$ with some $\mathrm{Al}, \mathrm{Ca}, \mathrm{Cl}, \mathrm{Fe}, \mathrm{K}, \mathrm{Mg}$, and $\mathrm{Na}$ (in order of decreasing abundance). The interlocking dolomite crystals, which range in diameter from 10 to $50 \mu \mathrm{m}$, show planar intergranular boundaries typical of idiotopic-s or planar-s fabrics (Sibley, 1982; Sibley and Gregg, 1987). The dolomite rhombs form $80 \%$ of the matrix, and zoned dolomite rhombs contain a Ca-rich center. Foraminifers (5\%) occur scattered through the matrix. The outlines of their tests are well preserved, but the tests have been completely or partially filled by rhombs of ferroan carbonate, crystals of kaolinite, opal-CT, large crystals of sparite $(50 \mu \mathrm{m})$, large dolomite rhombs $(100 \mu \mathrm{m})$, and pyrite (Plate 2).

Physical properties measurements show a downhole increase in bulk density of $0.6 \mathrm{~g} / \mathrm{cm}^{3}$ from the upper Oligocene siltstones to the upper Eocene chalks (Mountain, Miller, Blum, et al., 1994). The bulk density changes begin $\sim 100 \mathrm{~m}$ above the unconformity which suggest that the rise in bulk density is related to increased diagenesis and matrix cementation associated with the unconformity rather than to the lithological change between the siltstones and the chalks. Another change associated with the unconformity is the occurrence of abundant brown glauconites in the upper Oligocene silty claystones that suggest sediment reworking (Pekar et al., Chapter 15, this volume).

The second unconformity separates middle Eocene Zone NP16 from uppermost middle Eocene Zone NP17 (Aubry et al., 1996). It appears that this is another widespread unconformity in the New Jersey margin, because DSDP Site 612 and onshore wells are also associated with an unconformity at this interval (Aubry et al., 1996). An increase in the abundance of foraminifers from $20 \%$ to $50 \%$, more foraminiferal tests filled with ferroan carbonates than with opal-CT or chert, abundant former fluid routes, and sediment reworking of NP16 nannofossil taxa into Zone NP17 (Aubry et al., 1996), occur above the unconformity from $\sim 1128$ to 1125 mbsf. A slight decrease in the calcium carbonate and a slight increase in the opal content of the sediment also occur above the unconformity at $1125 \mathrm{mbsf}$.

\section{Sediment Above the Impact Ejecta}

Impact ejecta containing coesite and shocked quartz, orthoclase, and plagioclase feldspar was found at Site 903 (Glass and McHugh,

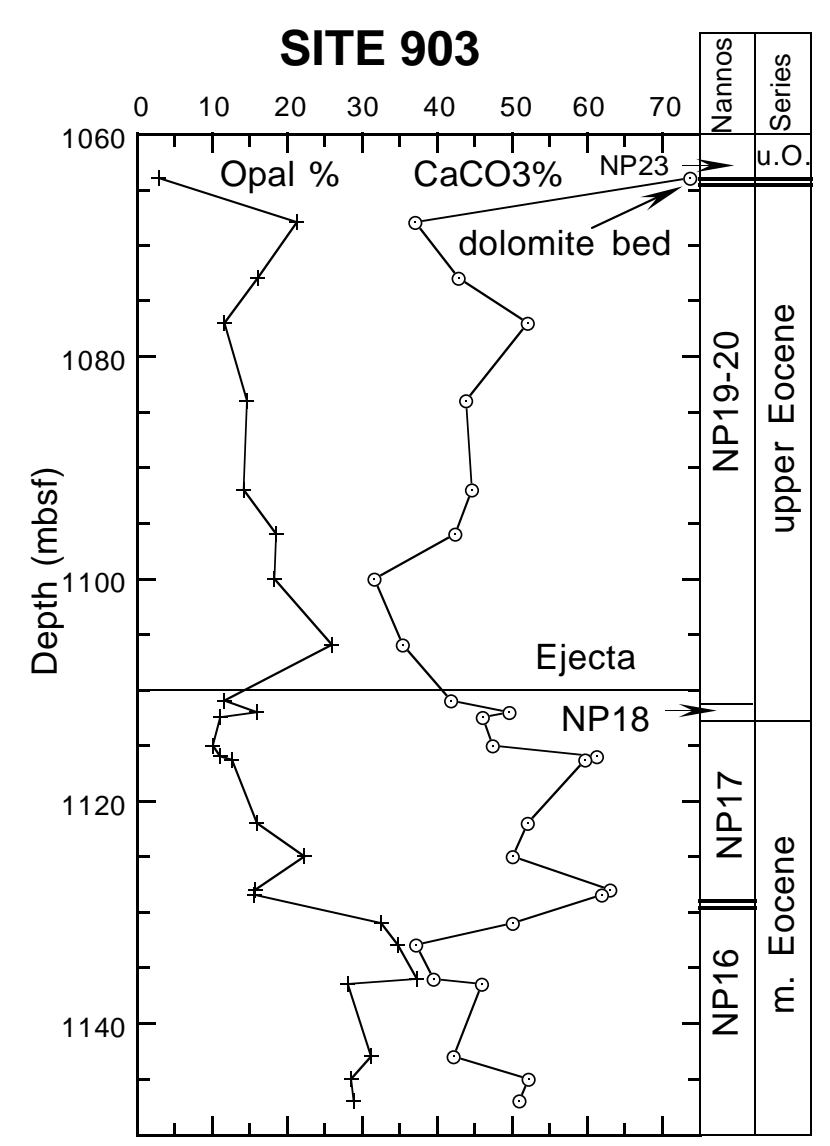

Figure 3. Biogenic opal and calcium carbonate content vs. depth for Site 903. Biostratigraphic nannoplankton zones and age of two unconformities (double lines): one between the upper Eocene and upper Oligocene and the second in the middle Eocene. The ejecta layer occurs at $1110.08 \mathrm{mbsf}$. Note correlation between high calcium and low opal and vice-versa.

1996). The ejecta is concentrated in a 3-cm-thick interval between 1110.08 and 1110.05 mbsf (interval 150-903-56R-6, 25-28 cm). Several changes are observed for $1 \mathrm{~m}$ above the ejecta layer: (1) ferroan carbonates and dolomite decrease from $10 \%$ to $2 \%$, (2) quartz increases from $1 \%$ to $15 \%$ and shows evidence of shock metamorphism, (3) glauconite increases from $2 \%$ to $5 \%$, and (4) opal content increases $\sim 10 \%$ (Fig. 3; Table 3). Quartz and glauconite are also abundant immediately above $(20 \mathrm{~cm})$ the tektite horizon at Site 904 (Mountain, Miller, Blum, et al., 1994; McHugh et al., 1996b) and at Site 612 (Glass, 1989). The calcium carbonate content of the sediment progressively decreases for $10 \mathrm{~m}$ above the ejecta to a minimum value of $31.67 \%$ at $1100 \mathrm{mbsf}$ (Fig. 3). This may or may not be related to the impact event because the trend towards lower calcium carbonate begins prior to the ejecta layer; however, at $1100 \mathrm{mbsf}$ the calcium carbonate value is the lowest measured for the Eocene at Site 903.

\section{Site 906}

\section{Petrography}

The upper Eocene sediment (Zones NP19-20 and Zones P15P17) recovered at Hole $906 \mathrm{~A}$ is $38.6 \mathrm{~m}$ thick and was badly disturbed during coring (Mountain, Miller, Blum, et al., 1994). The sediment is composed of light greenish gray biosiliceous, chalks. The few samples studied reveal that the matrix is primarily composed of micrite and opal. In most samples, fluid pathways are evident over $10 \%$ of 
1077

1084

1096

1100

1106

1109

1109.6

1110

1111

1112

1112.5 late Eocene NP19-20 $46.11 \quad 11.15$

111

111

1116.3 mid. Eocene NP17 $\quad 59.74 \quad 12.71$

1122

1128

1128.5

1131

1133

1136

1143

1145

1147
Description

5 Mosaic of euhedral to subhedral dolo rhombs; forams rplcd by sparite, dolo, opal.

Matrix: micrite, opal, and clay, fp $10 \%$; frctrs: $30 \%$, numerous orientations oblique to bedding; forams, few filled w/ opal, sparite, and dolo, one large burr ( $2 \mathrm{~mm}$ ).

. w/ opal, sparite, and dolo; two large burrows $(2 \mathrm{~mm})$
Matrix: micrite, opal, and clay, fp10\%; frctrs: $30 \%, \mathrm{num}$

30\% numerous orientations oblique to bedding; forams, few filled w/ opal, sparite, and dolo

Forams: ghosts, filled w/ dolo, sparite, opal? small $(100 \mu \mathrm{m})$; frctrs $30 \%$ oblique, orth, and parallel to bedding fractures oblique to bedding $10 \%$.

50 Matrix: micrite, opal, and clay, fp $10 \%$; frctrs: $30 \%$, numerous orientations oblique to bedding; forams, few filled w/

60 Matrix: micrite, opal, and clay, fp $10 \%$; frctrs: $10 \%$, parallel to bedding; forams, few filled w/ opal, sparite, and

43 Matrix: micrite, opal, and clay, fp 5\%; frctrs: $5 \%$, parallel to bedding; forams, few filled w/ opal and sparite qtz: stressed (extinction> $>5^{\circ}$ ), $100 \mu \mathrm{m}$

67 Matrix: micrite, opal, and clay, fp $5 \%$; frctrs: $1 \%$, parallel to bedding; forams, few filled w/ opal and sparite; qtz:

stressed (extinction $>15), 100 \mu \mathrm{m}$.
Matrix: micrite, opal, and clay, fp $75 \%$

$75 \%$ (patches of opal, micrite, and dolomicrite?); forams filled w/ opal and large crystals of sparry calcite $(500 \mu \mathrm{m})$.

; frctrs: $30 \%$, parallel, oblique, and ortho. to bedding; forams, well prsrvd, filled w/ opal, sparry calc and replaced by dolo (crystals $\sim 500 \mu \mathrm{m}$ ), form pockets at least three episodes of

cementation.
Matrix: micrite, opal, and clay, fp 20\%; frctrs: $20 \%$, parallel, oblique, and ortho. to bedding; forams, well prsrvd., filled $\mathrm{w} / \mathrm{opal}$, sparry calc and replaced by dolo (crystals $\sim 500 \mu \mathrm{m}$ ) at least three episodes of cementation; large burrow.

50 Matrix: micrite, opal, and clay, fp 20\%; frctrs: $20 \%$, parallel, oblique, and ortho. to bedding; forams, well prsrvd. filled w/ opal, sparry calc. and replaced by dolo (crystals $\sim 500 \mu \mathrm{m}$ ) at least three episodes of cementation.

45 Matrix: micrite, opal, and clay, fp 30\%; frctrs: $30 \%$, parallel, oblique, and ortho. to bedding; forams, well prsrvd filled $\mathrm{w} / \mathrm{opal}$, sparry calc and replaced by dolo (crystals $\sim 500 \mu \mathrm{m}$ ) at least three episodes of cementation.

45 Matrix: micrite, opal, and clay, fp 30\%; frctrs: $30 \%$, parallel, oblique, and ortho. to bedding; forams, well prsrvd filled w/ opal, sparry calc. and replaced by dolo (crystals $\sim 500 \mu \mathrm{m}$ ), at least three episodes of cementation.

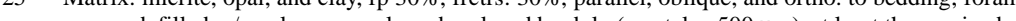
prsrvd, filled w/ opal, sparry calc and replaced by dolo (crystals $\sim 500 \mu \mathrm{m}$ ), at least three episodes of cementation
Matrix: micrite, opal, and clay, fp $30 \%$; frctrs: $30 \%$, parallel, oblique, and ortho to bedding: forams abndnt, well

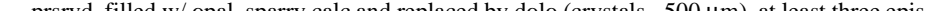
prsrvd, ficrite, opal, and clay, fp $30 \%$; frctrs: $30 \%$, parallel, oblique, and ortho to bedding; forams abndnt, well
Matrix: micrite Matrix: micrite, opal, and clay, fp 50\%; frctrs: $30 \%$, parallel, oblique, and ortho to bedding; forams abndnt, well
polion. prsrvd, filled w/ sparry calc. and replaced by dolo (crystals 500 um) at least three episodes of cementation. Matrix: micrite, opal, and clay, fp $50 \%$; frctrs: $5 \%$, parallel and oblique to bedding; forams abndnt, well prsrvd, filled $\mathrm{w} / \mathrm{sparry}$ calc and replaced by dolo (crystals $\sim 500 \mu \mathrm{m}$ ), at least three episodes of cementation

Matrix: micrite, opal, and clay, fp 40\%; fretrs: $\%$, parallel and oblique to bedding; forams well prsrvd, filled w/ opal, sparry calc and replaced by dolo (crystals $\sim 500 \mu \mathrm{m}$ ), at least three episodes of cementation.

40 Matix: mille, opal, and clay, fp 15\%, frctrs. 15\%, parallel and oblique to bedding, forans well prsrvd, filled w/

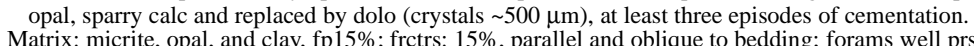

(illed w/ opal, sparry calc. and replaced by dolo (crystals $\sim 500 \mu \mathrm{m}$ ) at least three episodes of cementation.

$10 \%$, parallel and oblique to bedding; for sparry calc and replaced by dolo (crystals $\sim 500 \mu \mathrm{m}$ ); at least three episodes of cementation.

40 Matrix: micrite, opal, and clay, fp 5\%; frctrs: $20 \%$, parallel and oblique to bedding; forams well prsrvd, filled w/ sparry calc and replaced by dolo (crystals $\sim 500 \mu \mathrm{m}$ ), at least three episodes of cementation-

40 Matrix: micrite, opal, and clay, fp10\%; frctrs: $20 \%$, parallel and oblique to bedding; forams well prsrvd, filled w/ sparry calc and replaced by dolo (crystals $\sim 100 \mu \mathrm{m}$ ); at least three episodes of cementation.

Notes: Nannos $=$ nannofossils, Dolo $/ \mathrm{Fe}=$ dolomite/iron carbonates, Calc. $=$ calcite, Diat $=$ diatoms, rads $=$ radiolarians, Forams $=$ foraminifers, Glauco $=$ glauconite. Orth $=$ orthogonal, prsrvd $=$ preserved, $\mathrm{w} /=$ with, $\mathrm{fp}=$ fluid pathways, ang $=$ angular, frcts $=$ fractures, abndnt $=$ abundant. NM $=$ no measurements obtained. Sand, silt, and clay are the grain sizes of the thin section and total 100\%; dolo/Fe, calc (sparry calcite cement), diat/rads, foram, glauco, opaques, quartz, and matrix $=100 \%$ of thin section and are estimated values. The calcium carbonate is expressed as wt $\%$, assuming all the carbonate present in the sample was calcite (see "Methods" section, this chapter). In some instances the estimated biogenic silica value doesn't match the opal wt\%. 
A

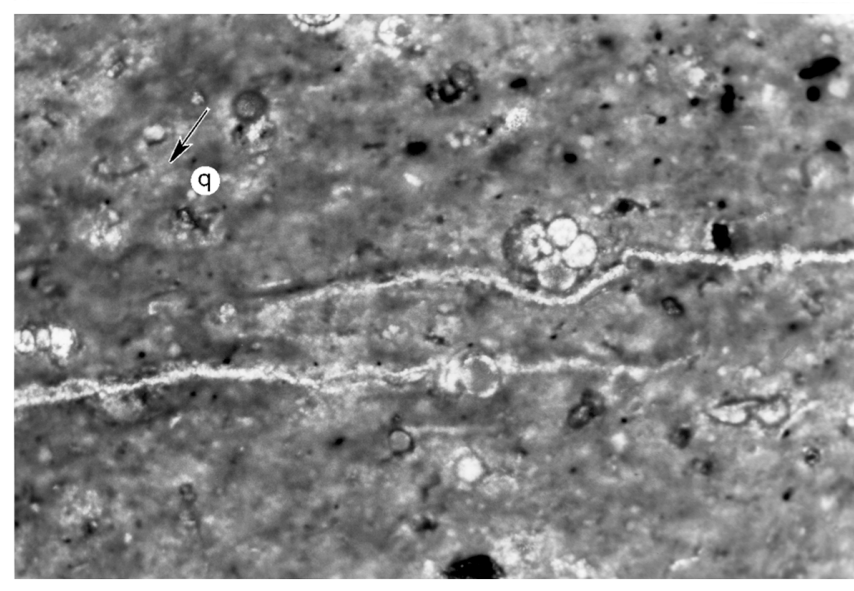

B

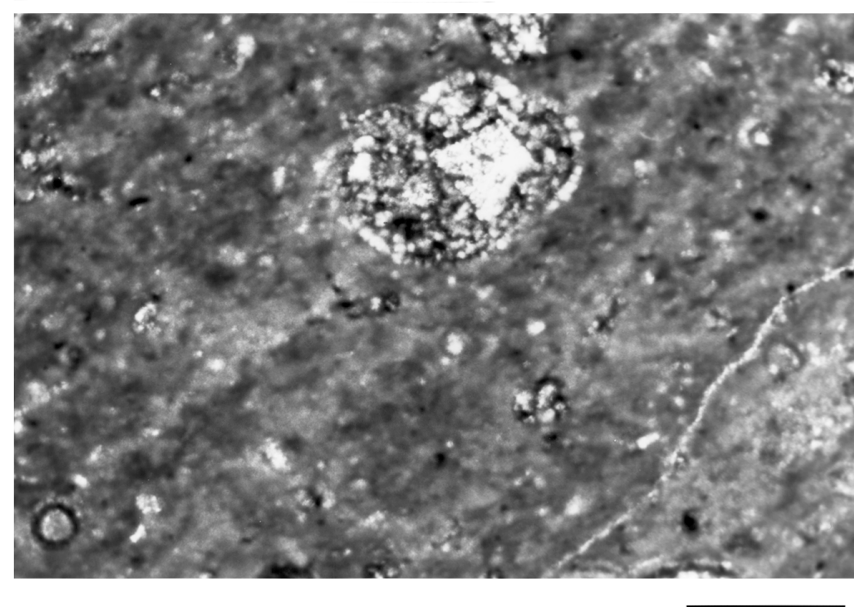

Figure 4. Thin sections of typical Eocene at Site 903. A. Upper Eocene foraminifers with well-preserved tests (note pseudo uniaxial cross in large foraminifera above unmineralized microfracture), quartz (q), and opaque minerals (bar $=500 \mu \mathrm{m}$; cross-nicols; $1077 \mathrm{mbsf}$ ). B. Ferroan dolomite commonly fills the tests of foraminifers (cross-nicols; $1084 \mathrm{mbsf}$ ). Note large dolomite rhomb in center of test.

the thin section's surface. Microfractures occur parallel and oblique to bedding, but they could have resulted from the extrusion of the cores. Normally, microfractures occur within fluid pathways, which is not the case in these samples.

In contrast to Hole 903C, foraminifers at Site 906 are not very abundant (5\%-10\%); some maintain their primary cementation and the majority are filled with opal (Table 4). Ferroan carbonates and dolomite are minor components at Site 906 and only observed in a few samples. At Site 906, as at Site 903, the carbonate content of the sediment (37\%-54\%; Fig. 5) is greater than in the coastal plain. Opal content ranges from $10 \%$ to $16 \%$. Another similarity between the upper Eocene sediment of Sites 906 and 903 is the occurrence of detrital quartz $(5 \%-10 \%)$ and glauconite $(\sim 5 \%)$ that are generally less abundant than at the coastal plain.

\section{Unconformity}

One unconformity between the upper Eocene and upper Oligocene is associated with the sediment recovered at Site 906 (Fig. 5). Core recovery between the upper Eocene biosiliceous clayey chalks and upper Oligocene silty claystones was poor. Sediment sampled at the top of the Eocene section at 563.96 mbsf is characteristic of the upper Eocene, with few foraminifers predominantly filled with opal, ghosts of diatoms or radiolarians, and minor ferroan carbonates, dolomite, detrital quartz, and glauconite. X-ray analyses of the upper Oligocene silty claystone above the unconformity $(546.4,529$, and $479.5 \mathrm{~m}$ ) show that the sediment contains abundant quartz, glauconite, some calcite, and minor feldspar, siderite, and pyrite. The calcium carbonate content for the intervals 546.4, 529, and $479.5 \mathrm{mbsf}$ is $13.13 \%, 19.18 \%$, and $30.08 \%$, respectively. Lower calcium carbonate values than the Eocene are typical for the Oligocene. The dominant clays for the upper Oligocene are illite, kaolinite, and minor smectite (McHugh et al., 1996a).

\section{Correlative Sediment to the Impact Ejecta?}

A horizon that may be approximately correlative in age to the ejecta layer at Sites 903, 904, and DSDP Site 612 and to the mixed assemblage interval of the Atlantic City and Island Beach boreholes (Poag, Watts, et al., 1987; Mountain, Miller, Blum, et al., 1994; Miller, Chapter 1, this volume) occurs at Site 906. At $600 \mathrm{mbsf}$, a mixed assemblage of middle Eocene foraminifers, which normally occurs at Eocene Zone P14, occurs within the late Eocene zonal interval P15-P17 (Mountain, Miller, Blum, et al., 1994). The specimens are possibly reworked, but their excellent preservation and abundance suggests minimal exposure to abrasion and chemical alteration (Mountain, Miller, Blum, et al., 1994). Except for an increase in detrital quartz at $593.5 \mathrm{~m}$, and mixed foraminifer assemblages, nothing unusual is observed in the sediment that might relate this interval directly to the impact ejecta.

\section{Site 902}

\section{Petrography}

The upper Eocene sediment (Zones NP19-20 and Zones P15P17) recovered at Hole 902D is $55.5 \mathrm{~m}$ thick (Mountain, Miller, Blum, et al., 1994). Unfortunately, the sediment was badly disturbed during the coring operation (Mountain, Miller, Blum, et al., 1994). Upper Eocene sediment at Site 902 is composed of light greenish gray biosiliceous, clayey nannofossil chalks which is very similar to the Eocene at Site 906. It contains $\mathrm{CaCO}_{3}(30 \%-60 \%$, Fig. 6), opal $(7 \%-20 \%)$, detrital quartz $(2 \%-10 \%)$, and glauconite $(5 \%-10 \%$, Table 5). $\mathrm{CaCO}_{3}$ decreases upsection and in the upper Oligocene at 648, 627.2 , and 618 mbsf; the $\mathrm{CaCO}_{3}$ level at these depths is $10.57 \%$, $14.88 \%$, and $17.4 \%$, respectively.

As at Site 906, foraminifers at Site 902 are not very abundant (generally 10\%; Table 5). Foraminifers are well preserved and some maintain their primary cementation. Foraminiferal tests are commonly filled with opal-CT. Some foraminiferal tests are filled with sparry calcite and ferroan carbonates. The matrix is composed predominantly of micrite and opal. Former fluid migration routes are evident within $10 \%$ of the matrix. Microfractures occur within these pathways.

\section{Unconformity}

One major unconformity associated with the upper Eocene and upper Oligocene contact was recovered at Site 902. This unconformable surface at $680.8 \mathrm{mbsf}$, is characterized by a striking lithological contact between light greenish gray upper Eocene biosiliceous clayey chalks and dark brown upper Oligocene glauconite-rich silty claystones (Mountain, Miller, Blum, et al., 1994). The sediment immediately beneath the unconformable surface $(680.9 \mathrm{mbsf})$ consists of a mosaic of euhedral to subhedral interlocking dolomite crystals (Mountain, Miller, Blum, et al., 1994), which show planar intergranular boundaries typical of idiotopic-s or planar-s fabrics (Sibley, 1982; Sibley and Gregg, 1987). The fabric is similar to the one found beneath the unconformity that separates the upper Eocene (Zones NP19-20) biosiliceous chalks from the upper Oligocene (Zone NP23) glauconitic sandy siltstones at Hole 903C (Mountain, Miller, 
Table 4. Hole 902D petrology.

\begin{tabular}{|c|c|c|c|c|c|c|c|c|c|c|c|c|}
\hline $\begin{array}{l}\text { Depth } \\
\text { (mbsf) }\end{array}$ & $\begin{array}{c}\text { Age } \\
\text { (nannos/forams) }\end{array}$ & $\begin{array}{l}\mathrm{CaCO}_{3} \\
(\mathrm{wt} \%)\end{array}$ & $\begin{array}{c}\text { Opal } \\
(\text { wt } \%)\end{array}$ & Dolo/Fe & Calc. & $\begin{array}{l}\text { Diatoms/ } \\
\text { radiolarians }\end{array}$ & Foram & Glauco & Opaques & Quartz & Matrix & Description \\
\hline 681 & late Eocene NP19/20 & 45.14 & 7.56 & 0 & 0 & Ghosts-10 & 10 & 10 & 10 & 10 & 50 & $\begin{array}{l}\text { Matrix: micrite and opal; fractures, } \\
\text { forams filled w/opal }\end{array}$ \\
\hline 684 & $\begin{array}{l}\text { P16-17 } \\
\text { late Eocene NP19/20 } \\
\text { P16-17 }\end{array}$ & 48.92 & 9.6 & 0 & 0 & Ghosts-10 & 10 & 5 & 10 & 5 & 60 & $\begin{array}{l}\text { Fp10\%. } \\
\text { Matrix: micrite and opal; ab ghosts of } \\
\text { rads? } \\
\text { Forams filled w/ opal, fp } 10 \% \text {, frcts } 10 \% \text { - } \\
\text { core was damaged during extrusion? }\end{array}$ \\
\hline 692 & late Eocene NP19/20 & 42.89 & 14.15 & 5 & 0 & Ghosts-15 & 10 & 5 & 10 & 5 & 50 & $\begin{array}{l}\text { Matrix: micrite and opal; few forams; ab } \\
\text { ghosts of rads? }\end{array}$ \\
\hline 705 & $\begin{array}{l}\text { P16-17 } \\
\text { late Eocene NP19/20 } \\
\text { P16-17 }\end{array}$ & 43.46 & 9.93 & 5 & 0 & Ghosts-10 & 10 & 5 & 10 & 5 & 55 & $\begin{array}{l}\text { Fp } 10 \% \text {, frcts } 10 \% \\
\text { Matrix: micrite and opal; few forams; ab. } \\
\text { ghosts of rads? } \\
\text { Fp } 10 \% \text {, frcts } 10 \% \text {. }\end{array}$ \\
\hline 711 & late Eocene NP19/20 & 42.95 & 15.24 & 5 & 0 & Ghosts-15 & 10 & 5 & 10 & 5 & 50 & $\begin{array}{l}\text { Matrix: micrite and opal; few forams; ab } \\
\text { ghosts of rads? }\end{array}$ \\
\hline 722.7 & $\begin{array}{l}\text { P16-17 } \\
\text { late Eocene NP19/20 } \\
\text { P16-17 }\end{array}$ & 37.53 & 18.7 & 2 & 0 & Ghosts-20 & 5 & 10 & 15 & 10 & 48 & $\begin{array}{l}\text { Fp } 10 \% \text {, frcts } 10 \% \text {. } \\
\text { Matrix: micrite and opal; broken forams; } \\
\text { ab ghosts of rads? } \\
\text { Fp } 15 \% \text {, frcts } 30 \% \text {. }\end{array}$ \\
\hline 726 & late Eocene NP19/20 & 31.86 & 17.42 & 2 & 0 & Ghosts-20 & 10 & 5 & 15 & 2 & 46 & $\begin{array}{l}\text { Matrix: micrite and opal; few forams; ab } \\
\text { ghosts of rads? }\end{array}$ \\
\hline 733 & $\begin{array}{l}\text { P16-17 } \\
\text { late Eocene NP19/20 }\end{array}$ & 30.10 & 19.42 & 2 & 0 & Ghosts-20 & 10 & 5 & 15 & 2 & 46 & $\begin{array}{l}\text { Fp } 15 \% \text {, frcts } 30 \% \text {. } \\
\text { Matrix: micrite and opal; few forams; ab. } \\
\text { ghosts of rads? }\end{array}$ \\
\hline 740 & $\begin{array}{l}\text { P16-17 } \\
\text { late Eocene NP19/20 } \\
\text { P16-17 }\end{array}$ & 59.98 & 14.81 & 20 & 0 & Ghosts-15 & 40 & 5 & 10 & 0 & 10 & $\begin{array}{l}\text { Fp 5\%, frcts } 30 \% \text {. } \\
\text { Reworked m.Eo. good preservation, } \\
\text { wasn't transported far } \\
\text { Forams: filled w/dolo, sparite, and opal, } \\
\text { forms well prsrvd, fp } 30 \% \text {,frcts } 10 \% \text {; } \\
\text { matrix: micrite and opal. }\end{array}$ \\
\hline
\end{tabular}

Notes: Nannos = nannofossils, Dolo/Fe = dolomite/iron carbonates, Calc. $=$ sparry calcite cement, Foram $=$ foraminifers, and Glauco $=$ glauconite. $\mathrm{W} /=$ with, fp $=$ fluid pathways, frcts $=$ fractures, and $\mathrm{ab}=$ abundant. Grain sizes of thin section are silt to clay and have not been estimated as percentages. Dolo/fe, calc., diatoms/radiolarians, foram, glauco, opqs, qtz, and $\mathrm{mtx}=100 \%$ of thin section and are estimated values. The calcium carbonate is expressed as wt $\% \mathrm{CaCO}_{3}$ assuming all the carbonate present in the sample was calcite (see "Methods" section, this chapter). In some instances the estimated biogenic silica value doesn't match the opal wt\%.

Blum, et al., 1994). Clays associated with the upper Eocene are mixed illite/smectite (70\%) and illite (30\%; McHugh et al., 1996a). However, adjacent to the unconformity at $684 \mathrm{mbsf}$, there is kaolinite (10\%; McHugh et al., 1996a). The upper Oligocene above the unconformity contains illite (50\%), kaolinite (30\%), and mixed illite/smectite (20\%; McHugh et al., 1996a).

\section{Correlative Sediment to the Impact Ejecta?}

Nannofossil biostratigraphy indicates that a complete uppermost Eocene section (Zones NP19-20) was recovered at Site 902. The upper Eocene section extends from 740 to 680 mbsf. At 740.1 mbsf, upper middle Eocene planktonic foraminifers are mixed within upper Eocene sediment (Snyder, et al., 1996). The foraminifers are reworked but very well preserved, suggesting that they were not transported far from their original site of deposition (Mountain, Miller, Blum, et al., 1994). Foraminiferal abundances increase at this interval from $10 \%$ to $40 \%$, ferroan carbonates and dolomite increase from $2 \%$ to $20 \%$, and $\mathrm{CaCO}_{3}$ is also higher at $60 \%$ (Fig. 6; Table 4). Except for the changes in foraminiferal assemblages, increased diagenesis, and $\mathrm{CaCO}_{3}$, there is nothing else that correlates this interval to the impact ejecta.

\section{Site 904}

\section{Petrography}

The Eocene at Hole 904A is $235.5 \mathrm{~m}$ thick and extends from the upper lower Eocene (Subzone NP14, Zones P9-P10) to the upper Eocene (Zones NP19-20, Zones P16-P17; Mountain, Miller, Blum, et al., 1994). As at other slope sites the occurrence of detrital quartz is minor $(<1 \%-10 \%)$ at Site 904 (Table 6). Quartz is concentrated in the upper part of the upper Eocene and, except for the ejecta layer, is rare to absent in the rest of the section. Glauconite follows the same trend as quartz, being a minor $(<5 \%)$ component of the sediment and concentrated in the upper Eocene. Calcium carbonate content decreases towards the Oligocene at Site 904, as at Site 903 (Fig. 7).

Foraminifers are common in the upper Eocene (Zones NP19-20) and constitute $5 \%-20 \%$ of the sediment. The outline of their tests is noted by red rims and except for a few intervals in which sparry calcite occurs, foraminiferal tests are partially to completely filled with opal-CT (Plate 3). In contrast to Sites 903 and 902, dolomite and ferroan carbonates are rare at Site 904, except for an interval that extends from 470 to 446 mbsf (middle Eocene Zones NP15-16 to middle Eocene Zone NP16; Mountain, Miller, Blum, et al., 1994).

Middle Eocene sediment is characterized by foraminiferal abundances that range between $5 \%$ and $20 \%$. Carbonate diagenesis is patchy because some foraminifers still preserve their primary cementation whereas others have been partly replaced by sparite and/or opal-CT (Plate 3). Silica cement is the most prevalent type.

Diatom and radiolarian tests occur in the upper Eocene, but only their ghosts, revealed by the outline of the tests that are filled with opal-CT and/or chert, are noted downhole (Plate 3). The increased dissolution with depth of the opaline tests is consistent with the progression of silica diagenesis with burial (Riech and von Rad, 1979; Thein and von Rad, 1987). Opaline tests are evident until 490 mbsf; below this depth, ghosts predominate. Opal content of the Eocene ranges from $8 \%$ to $45 \%$, with higher percentages for the middle Eocene, as at Site 903 (Fig. 7). Physical properties measurements show a significant increase of $0.4 \mathrm{~g} / \mathrm{cm}^{3}$ in bulk density values at 525.24 mbsf that correlate with a decrease in water content and porosity (Mountain, Miller, Blum, et al., 1994). Lithologically, these changes correlate with an increase in former fluid migration pathways downhole and, presumably, with increased silica cementation of the matrix.

\section{Unconformities}

Three unconformities are associated with the Eocene at Site 904 (Fig. 7). The youngest unconformity, which is also lithologically the 


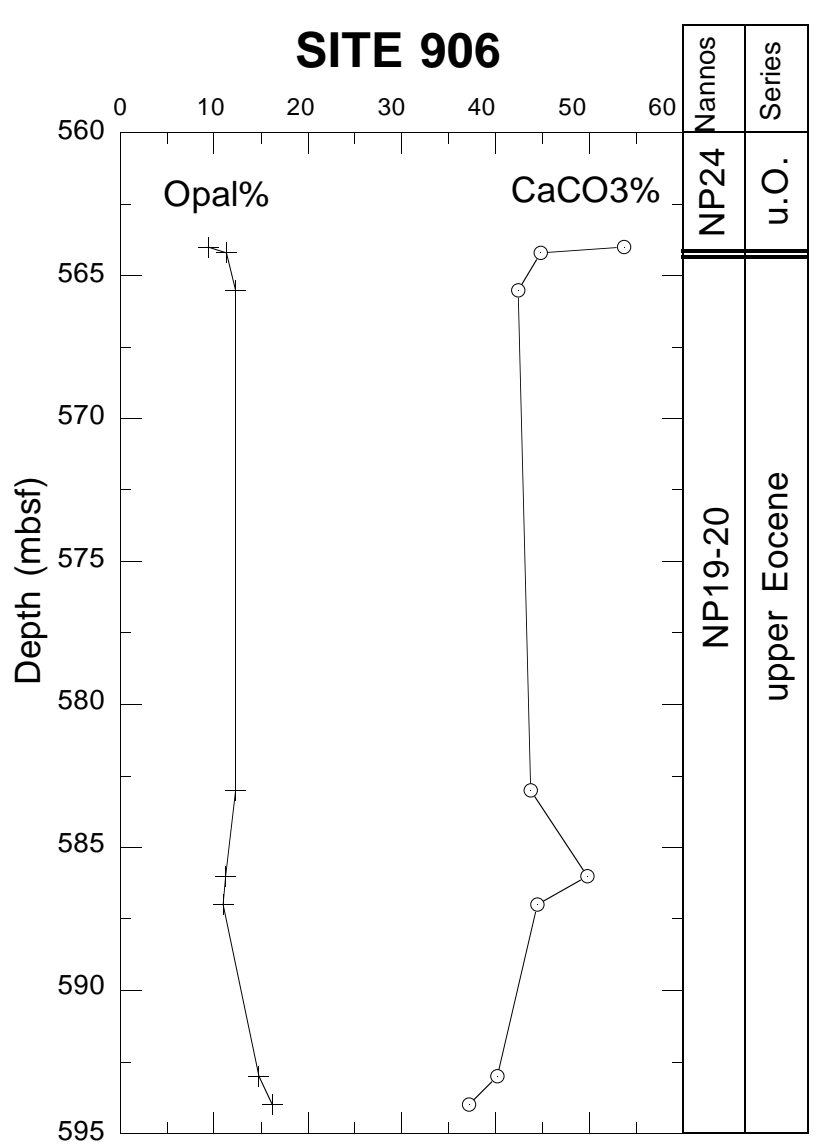

Figure 5. Biogenic opal and calcium carbonate content vs. depth for Site 906. Biostratigraphic nannoplankton zones and age of one major unconformity (double lines) that separates upper Eocene from upper Oligocene sediment. Poor core recovery did not permit closer sampling intervals.

most evident, separates upper Eocene from upper Oligocene sediment (Mountain, Miller, Blum, et al., 1994; Aubry et al., 1996). The contact at $341.21 \mathrm{mbsf}$ separates glauconitic sandy silty clay above from biosiliceous nannofossil chalks below. Sediment $40 \mathrm{~cm}$ below this contact is characteristic of the late Eocene, as described in the section above. The only difference is the occurrence of glauconite, which is $5 \%$ more abundant than in the rest of the Eocene section. Glauconite grains occur in clusters with minor detrital quartz and foraminifers. The clusters are associated with abundant patches of darkstained micrite. Foraminifers are filled with two types of cement: $\mathrm{Si}$, $\mathrm{Cl}, \mathrm{Ca}, \mathrm{Al}, \mathrm{Mg}, \mathrm{Na}$, and $\mathrm{K}$ (in order of decreasing abundances) and $\mathrm{Si}, \mathrm{Al}$, and minor $\mathrm{Mg}, \mathrm{Na}, \mathrm{Cl}, \mathrm{K}$, and $\mathrm{Fe}$. Most glauconite grains are surrounded by a yellowish diagenetic halo. The matrix is stained by former fluid pathways and shows evidence of alteration. The matrix is composed of $\mathrm{Si}, \mathrm{Al}, \mathrm{Ca}, \mathrm{Cl}, \mathrm{K}, \mathrm{Fe}$, and minor $\mathrm{Mg}$, and $\mathrm{Na}$. The glauconite content of the sediment, diagenetic halos, fluid pathways, and detrital quartz progressively decrease downhole from the unconformable surface. Abundant dark brown glauconite characterizes the upper Oligocene sediment above.

The second unconformity, at 423 mbsf, separates middle Eocene (Zone NP16) from upper Eocene (Zone NP18; Mountain, Miller, Blum, et al., 1994; Aubry et al., 1996). This unconformity also occurs in DSDP Site 612 and onshore wells, which suggests that it is widespread throughout the margin (Poag and Low, 1987; Poag and Aubry, 1995; Miller et al., 1994). Sediment immediately beneath the unconformity contains foraminifers with well-preserved tests and the matrix contains minor fluid pathways. Analyses of the matrix reveal that it is composed predominantly of $\mathrm{Si}$ with minor $\mathrm{Al}, \mathrm{Ca}, \mathrm{Cl}, \mathrm{Mg}$, and $\mathrm{Na}$. Some foraminifers maintain their primary cementation, but their tests are commonly filled with opal-CT or chert. Below the unconformity, down to $427 \mathrm{mbsf}$, the sediment contains broad fluid pathways over $10 \%$ of the matrix surface and clusters of foraminifers that suggest reworking (Fig. 8).

The oldest unconformity separates upper lower Eocene Subzone NP14a from middle Eocene Subzone NP15b (Mountain, Miller, Blum, et al., 1994; Aubry et al., 1996) at $~ 550$ mbsf. Core recovery was poor at this interval. This unconformity was also documented at DSDP Sites 612, 613, and 605 (Poag and Low, 1987; Olsson and Wise, 1987) and onshore boreholes (Miller et al., 1990; Miller et al., 1994). Sediment immediately below the unconformity is characterized by abundant fluid pathways that extend over $90 \%$ of the matrix (Plate 4). This is rather unusual, even for the early Eocene, where former fluid migration routes commonly occur as a result of silica diagenesis. Former fluid pathways are composed predominantly of $\mathrm{Si}$ some $\mathrm{Ca}$ and minor $\mathrm{Al}$. The matrix is very rich in silica, which at some intervals constitute $100 \%$ of the sediment.

Sediment above the unconformity is also characterized by abundant fluid pathways; but, in contrast to the sediment below, it contains numerous foraminifers that have been extensively altered and tend to be clustered, giving the appearance of reworking (Fig. 9). Foraminifers are filled with almost pure silica and SEM analyses show that foraminiferal tests are filled with recrystallized quartz (Plate 5). This indicates that silica diagenesis has gone one step further from opal-CT to quartz. White patches observed in petrographic thin sections of the matrix are rich in $\mathrm{Si}, \mathrm{Cl}$, and $\mathrm{Ca}$, and contain minor $\mathrm{Al}$, $\mathrm{Na}, \mathrm{Mg}$, and $\mathrm{Fe}$.

\section{Sediment Above the Ejecta Layer}

The ejecta layer composed of tektites, microtektites, and shocked quartz and feldspar occurs at Site 904 between 415.79 and 415.74 mbsf (McHugh et al., 1996b). As at Sites 902, 903, and 906, reworked middle Eocene foraminifers are mixed with upper Eocene sediment. At Sites 903 and 904 the reworked middle Eocene foraminifers occur above the ejecta layer. However, at Site 904, middle Eocene foraminifers occur for another $21 \mathrm{~m}$ above the layer (Mountain, Miller, Blum, et al., 1994; McHugh et al., 1996b). As at Site 903, the calcium carbonate of the sediment decreases for $10 \mathrm{~m}$ above the ejecta to the lowest values observed for the Eocene (32.8\% at 404.55 mbsf); but the decrease, as at Site 903, began prior to the ejecta being deposited (Fig. 7). Abundant fluid pathways, opaque minerals, and an $8 \%$ increase in the opal content characterize the sediment for $1 \mathrm{~m}$ above the ejecta layer. An increase in pyrite, quartz, and glauconite was also documented $20 \mathrm{~cm}$ above the ejecta at Site 904 (Mountain, Miller, Blum, et al., 1994).

\section{DISCUSSION}

\section{Diagenesis of Coastal Plain and Slope Sites}

Differences are noted in the diagenetic transformation and mineral composition of the sediment with progressive distance from the shoreline. The upper and middle Eocene of the coastal plain Atlantic City borehole are contrasted and compared to the upper and middle Eocene of the slope Sites. Only a small section of the lower Eocene at Site 904 is comparable to the lower Eocene of Island Beach. Generally, coastal plain sediment has undergone numerous episodes of carbonate diagenesis as documented in the tests of foraminifers: dissolution and recrystallization of the original test, infilling by micrite, finely crystalline sparite, rare replacement by dolomite and ferroan carbonates, and almost complete dissolution of tests. This type of cementation is more typical of the near-shore and near-surface environment, where pore-fluid flow rates are more active than in the offshore 


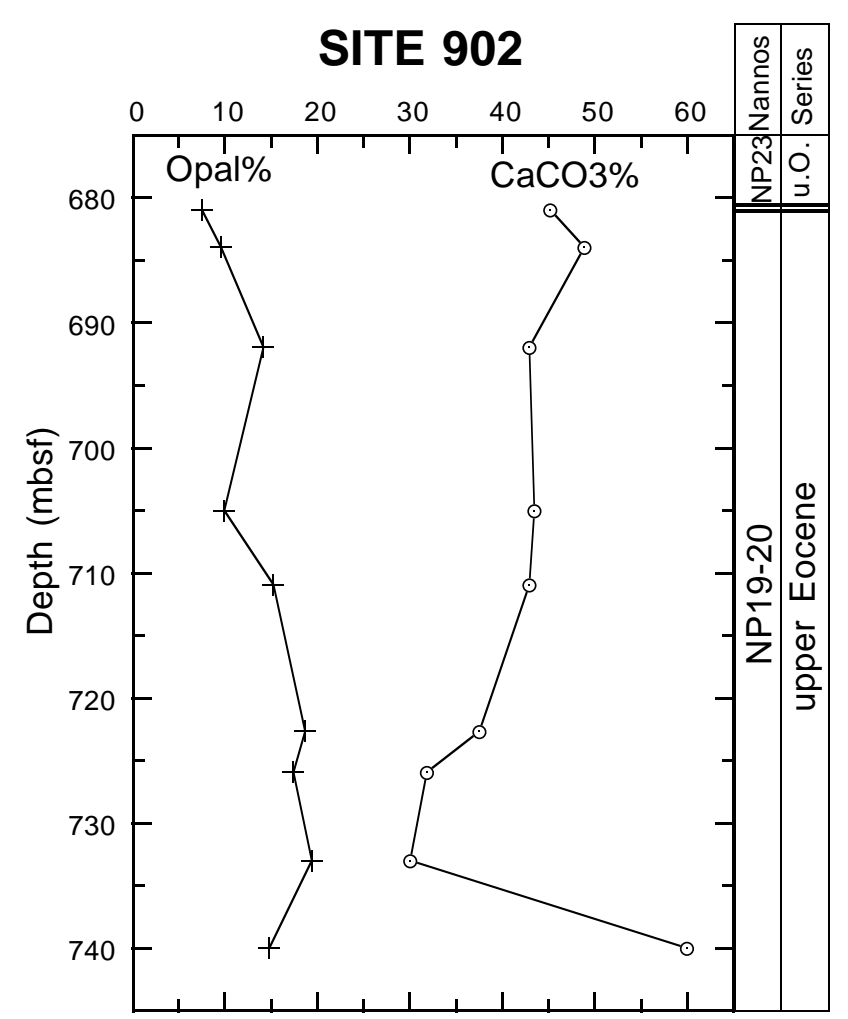

Figure 6. Biogenic opal and calcium carbonate content vs. depth for Site 902. Biostratigraphic nannoplankton zones and age of major unconformity (double lines) that separates upper Eocene from upper Oligocene sediment. Clusters of foraminifers occur at $740.1 \mathrm{mbsf}$, and their occurrence appears to correlate to higher calcium carbonate values.

burial environment (James and Choquette, 1983; 1984). More tests need to be conducted to determine the influence, if any, of meteoric fluids in the diagenetic transformations. Such influence has been extensive in the Eocene porcellanites exposed on the coastal plain. Here, practically all calcium carbonate has presumably been removed and the silica rich matrix has been completely recrystallized into an amorphous cement.

The transport of terrestrial sediment to the coastal plain and slope Sites is manifested in the occurrence of abundant detrital quartz and minor feldspar and mica. Glauconites form in the shallow-marine environment. They are particularly characteristic of the continental shelf at water depths between 60 and $500 \mathrm{~m}$ with optimum water depths of formation at $200 \mathrm{~m}$ (Odin and Matter, 1981). Most of the glauconite found below $200 \mathrm{~m}$ of water depth is likely to have been transported from shallow water (Odin and Matter, 1981).The occurrence of glauconites at the slope sites suggests shallow-water transport, and its correlation with quartz also suggests transport of terrigenous sediment. The range in colors of the glauconite grains, from different shades of green to brownish yellow and reddish brown at one location, indicates that the grains have been oxidized at different rates (Odin and Matter, 1981). Brown glauconites in lower Eocene sediment at Island Beach suggest sediment reworking (Pekar et al., Chapter 15, this volume). The occurrence of brown glauconites at the slope Sites suggests sediment reworking and transport from shallow water. The occurrence of gray glauconites at the Atlantic City borehole indicates an even more extensive diagenetic transformation to silica.

One of the major differences between the coastal plain and the slope carbonate diagenesis is the occurrence of coarsely crystalline ferroan carbonates and dolomite filling the foraminiferal tests at slope Sites 903 and 902. Less nucleation of crystallites and coarser crystal forms are typical of the burial environment where pore-fluid flow rates are very low (Choquette and James, 1987; Buddemeier and Oberdorfer, 1986). Finely crystalline sparry calcite is common in the coastal plain, which suggests more active pore-fluid flow. The occurrence of ferroan carbonates in the slope is an indication of the greater reducing nature of the pore fluids. The reducing conditions in which $\mathrm{Fe}$ and $\mathrm{Mn}$ tend to be preferentially picked up during diagenesis are brought about by the stagnation of the oxidizing waters and/or the thermal decomposition of organic matter in the sediment (von Rad and Botz, 1987).

Fewer episodes of carbonate diagenesis are observed at Site 904 than at Site 903; this is indicated by the foraminiferal tests that commonly maintain their primary cementation and are rarely filled with sparry calcite or ferroan carbonates. The carbonate content of middle and upper Eocene sediment at Sites 904 and 903 is similar so that the local variations in carbonate diagenesis between these two locations must have been caused by other reasons, including slower pore-fluid flow rates. Another indication of slower pore-fluid flow rates from the coastal plain to Sites 903 and 904 can be interpreted from the mineralization of microfractures. Coastal plain microfractures are always filled with silica suggestive of more active fluid flow. Microfractures are partly mineralized at Site 903 and rarely filled with silica at Site 904.

The silica diagenetic alterations in the slope biosiliceous chalks show a progression with increased burial from weakly silicified chalks to strongly silicified calcareous porcellanites. The diagenetic transformations are manifested by the dissolution of opaline silica tests, by opal-CT filled foraminiferal tests, by silica impregnating the matrix in a diffuse or patchy manner, and by the occurrence of microfractures caused by volume reduction after loss of crystallization water from the biogenic opal. Although silica diagenesis in the coastal plain is evident by the dissolution of opaline silica tests, microfracturing as a result of volume reduction is not as pervasive as at the slope. Coastal plain sediment contains an abundance of detrital minerals and less calcium carbonate (25\%-45\% less) than the slope. Experiments and studies of the Monterey Formation and other deep-sea drilling sites have shown that the host sediment has an effect on the rate at which the silica diagenetic transformations occur (Kastner et al., 1977; Isaacs, 1982; Hinman, 1990). The occurrence of detrital minerals and clay would tend to retard the opal-A to opal-CT transformation and enhance the opal-CT to quartz transformation, whereas the occurrence of calcite would have the opposite effect. Results from these studies suggest that mineral composition of coastal plain sediment has influenced the diagenetic path so that microfracturing and other features such as conchoidal surfaces, which are common in the lower slope calcareous porcellanites (McHugh et al., 1993), are rare to absent on the coastal plain where clay and detrital minerals are abundant. In addition, upper to middle coastal plain sediments at Atlantic City generally contain less opal than the slope sites.

In contrast to the coastal plain sediment, terrigenous and shallowwater sediment transport manifested by the occurrence of silt-sized detrital quartz and glauconite is minor at the slope sites and occurs predominantly in upper Eocene sediment. The influx of terrigenous sediment correlates with a decrease in the calcium carbonate and opal content of the chalks and these changes in sedimentation patterns are consistent with a gradual shift from an Eocene pelagic, carbonate-dominated margin to an Oligocene hemipelagic, siliciclasticdominated margin.

\section{Diagenesis of the Sediment at Unconformable Surfaces}

The most striking diagenetic transformations at the continental slope Sites occurred in upper Eocene sediment beneath the unconformable surface with the upper Oligocene (Fig. 10). The Eocene biosiliceous chalks have been transformed to an idiotopic mosaic of do- 
Table 5. Hole 906A petrology.

\begin{tabular}{|c|c|c|c|c|c|c|c|c|c|c|c|}
\hline $\begin{array}{l}\text { Depth } \\
\text { (mbsf) }\end{array}$ & $\begin{array}{c}\text { Age } \\
\text { (nannos-forams) }\end{array}$ & $\begin{array}{l}\mathrm{CaCO}_{3} \\
(\mathrm{wt} \%)\end{array}$ & $\begin{array}{l}\text { Opal } \\
(\mathrm{wt} \%)\end{array}$ & Dolo/Fe & $\begin{array}{l}\text { Diatoms/ } \\
\text { radiolarians }\end{array}$ & Foram & Glauco & Opaques & Quartz & Matrix & Description \\
\hline 564 & $\begin{array}{l}\text { late Eocene NP19/20 } \\
\text { P16-17 }\end{array}$ & 53.74 & 9.42 & 0 & Ghosts-10 & 10 & 0 & 10 & 5 & 65 & $\begin{array}{l}\text { Matrix: micrite and opal; forams: few } \\
\text { and filled w/opal; ab. ghosts of rads?; } \\
\text { frcts } 10 \% \text { parallel and oblique to } \\
\text { bedding }\end{array}$ \\
\hline 564.2 & $\begin{array}{l}\text { late Eocene NP19/20 } \\
\text { P16-17 }\end{array}$ & 44.84 & 11.36 & 0 & Ghosts-10 & 5 & 5 & 10 & 10 & 60 & $\begin{array}{l}\text { Matrix: micrite and chert; forams: few } \\
\text { and filled w/opal; ab. ghosts of rads? } \\
\text { one large burrow ( } 1 \mathrm{~mm}) \text {; frcts } 10 \% \\
\text { parallel and oblique to bedding. }\end{array}$ \\
\hline 565.5 & $\begin{array}{l}\text { late Eocene NP19/20 } \\
\text { P16-17 }\end{array}$ & 42.43 & 12.33 & 1 & Ghosts-10 & 5 & 5 & 10 & 5 & 64 & $\begin{array}{l}\text { Matrix: micrite and chert; forams: few } \\
\text { and filled w/opal;ab. ghosts of rads? } \\
\text { frcts } 10 \% \text { parallel and oblique to } \\
\text { bedding. }\end{array}$ \\
\hline 583 & $\begin{array}{l}\text { late Eocene NP19/20 } \\
\text { P15-17 }\end{array}$ & 43.74 & 12.31 & 0 & Ghosts-10 & 5 & 5 & 10 & 5 & 65 & $\begin{array}{l}\text { Matrix: micrite and chert; forams: few } \\
\text { and filled w/opal;ab. ghosts of rads? } \\
\text { frcts } 10 \% \text { parallel and oblique to } \\
\text { bedding. }\end{array}$ \\
\hline 586 & $\begin{array}{l}\text { late Eocene NP19/20 } \\
\text { P15-17 }\end{array}$ & 49.79 & 11.26 & 5 & Ghosts-10 & 10 & 5 & 20 & 0 & 50 & $\begin{array}{l}\text { Matrix: micrite and chert; forams: few } \\
\text { and filled w/opal,and dolo.; ab. ghosts } \\
\text { of rads? frcts } 20 \% \text { parallel, oblique, } \\
\text { and ortho to bedding. }\end{array}$ \\
\hline 587 & $\begin{array}{l}\text { late Eocene NP19/20 } \\
\text { P15-17 }\end{array}$ & 44.46 & 11 & 0 & Ghosts-10 & 10 & 5 & 15 & 5 & 55 & $\begin{array}{l}\text { Matrix: micrite and chert; forams: few } \\
\text { and filled w/opal; fp } 20 \% \text {; frcts } 50 \% \\
\text { parallel, oblique, and ortho to bedding; } \\
\text { ab. ghosts of rads? }\end{array}$ \\
\hline 593 & $\begin{array}{l}\text { late Eocene NP19/20 } \\
\text { P15-17 }\end{array}$ & 40.21 & 14.79 & 0 & Ghosts-15 & 10 & 5 & 10 & 10 & 50 & $\begin{array}{l}\text { Matrix: micrite and chert; forams: few } \\
\text { and filled w/opal; fp. } 5 \% \text {; frcts } 5 \%\end{array}$ \\
\hline 594 & $\begin{array}{l}\text { late Eocene NP19/20 } \\
\text { P15-17 }\end{array}$ & 37.21 & 16.23 & 0 & Ghosts-15 & 10 & 5 & 15 & 0 & 55 & $\begin{array}{l}\text { Matrix: micrite and chert; forams: few } \\
\text { and filled w/opal; fp. } 5 \% \text {; frcts } 10 \% \\
\text { oblique to bedding; ab. ghosts of rads? }\end{array}$ \\
\hline
\end{tabular}

Notes: Nannos $=$ nannofossils, Dolo/Fe $=$ dolomite/iron carbonates, Foram $=$ foraminifers, and Glauco $=$ glauconite $. \mathrm{W} /=$ with, $\mathrm{fp}=$ fluid pathways, frcts $=$ fractures, ortho $=$ orthogonal, ab. = abundant, $\mathrm{nm}=$ no measurements obtained. Grain sizes of thin section samples are silt to clay. Dolo/Fe, diatoms/radiolarians, foram, glauco, opaques, quartz, and matrix $=100 \%$ of thin section. The calcium carbonate is expressed as wt $\%$, assuming all the carbonate present in the sample was calcite (see "Methods" section, this chapter). In some instances the estimated biogenic silica doesn't match the opal wt $\%$.

lomite crystals. The micrite matrix has been completely replaced by dolomite rhombs, and dolomicrite and also contains kaolinite clay. However, the allochems have been preserved, although they have undergone several episodes of diagenesis. Analyses of petrographic relations based on the unimodal distribution of the dolomite rhombs, the planar crystal boundaries, and the relation of the allochems and matrix to the dolomite mosaic suggest slow grain growth under highly saturated dolomitizing fluids at low temperature. This interpretation is based on the classification proposed by Sibley and Gregg (1987). Dilution of seawater with meteoric waters and/or lowering of the $\mathrm{SO}_{4}$ content of the sediment (Tucker and Wright, 1990) are two of the possible mechanisms that may have contributed to dolomite precipitation.

Stratigraphic relations indicate that the uppermost dolomite bed is only a few centimeters thick. The sediment below the contact is not associated with mass-wasting. However, the silty clays and dark brown glauconite that occur in the Oligocene sediment above the unconformity at all slope sites, indicate terrigenous sediment transport and reworking from shallow water where the glauconites commonly form (Odin and Matter, 1981; Pekar et al., Chapter 15, this volume). Altered glauconite grains, detrital quartz, clay, and increased fluid pathways beneath the unconformity at Site 904 suggest minor sediment reworking and transport from shallow water for the late Eocene. More geochemical analyses need to be conducted to determine more precisely the source of the dolomitization fluids. However, the processes that occurred at this contact are unlike any others observed for the Eocene sediment, and the unconformity, which was documented at all slope sites (Mountain, Miller, Blum, et al., 1994), documents a major change in the sedimentation of the margin.

There is no evidence for sediment transport at the unconformable surface that separates middle Eocene Zone NP17 from Zone NP16 at Site 903. However, the increase in foraminifers and carbonate diagenesis, the abundance of former fluid routes, and the occurrence of
Zone NP16 nannofossil taxa in Zone NP17 suggest increased fluid activity and sediment reworking. Reworking of sediment suggested by clusters of foraminifers and a minor increase in pore-fluid activity are associated with the unconformity that separates middle Eocene Zone NP16 from upper Eocene Zone NP18 at Site 904. Middle Eocene Zone NP17 is missing at Site 904 (Aubry et al., 1996) and present at Site 903, which suggests slope erosion associated with the unconformity.

The oldest unconformity that separates upper lower Eocene Subzone NP14a from middle Eocene Subzone NP15b at slope Site 904 is associated with (1) sediment reworking (above), (2) abundant fluid pathways suggestive of increased pore-fluid flow activity (above and below), (3) an increase in silica diagenesis from opal-CT to quartz, and (4) the occurrence of kaolinite (Fig. 9).

Analyses of the matrix and former fluid pathways in sediment above and below the unconformities that separate the uppermost middle Eocene and the lower/middle Eocene suggest that the fluids originated from a local source within the Eocene sediment. The element composition of the matrix is the same as that of the fluid routes. The only difference is that calcium and/or silica tend to be concentrated within the darker stained pathways. EDX analyses show that chloride occurs in Eocene sediment and that its occurrence may be related to the diffusion of evaporites from deeper sources. Pore-fluid analyses of the slope sites also detected an increase in $\mathrm{Cl}$ and $\mathrm{Ca}$ with depth, and this increase was related to possible migration of brines from greater depths (Mountain, Miller, Blum, et al., 1994).

In general, evidence for physical processes such as increased former fluid migration routes and minor sediment reworking are common to the sediment associated with the Eocene unconformities. However, the chemical and physical changes increase in complexity from the late middle Eocene to the upper Eocene/upper Oligocene boundary. The diagenetic transformations that culminate in complexity at the upper Eocene/upper Oligocene boundary occurred in re- 


\begin{tabular}{|c|c|c|c|c|c|c|c|c|c|c|c|}
\hline $\begin{array}{c}\text { Depth } \\
(\mathrm{m})\end{array}$ & $\begin{array}{c}\text { Age } \\
\text { (nannofossils) }\end{array}$ & $\begin{array}{l}\mathrm{CaCO}_{3} \\
(\mathrm{wt} \%)\end{array}$ & $\begin{array}{c}\text { Opal } \\
(\mathrm{wt} \%)\end{array}$ & Dolo/Fe & Diat/rads & Foram & Glauco & Opaques & Quartz & Matrix & Description \\
\hline 341 & late Eocene NP 19-20 & 37.11 & 14.06 & 5 & 15 & 15 & 10 & 10 & 10 & 35 & $\begin{array}{l}\text { Pockets of forams, glauco, and qtz; fp patchy reworked- dolo rhombs in matrix forams: patchy to } \\
\text { opal, sparite, primary. }\end{array}$ \\
\hline 342 & late Eocene NP 19-20 & 39.57 & 15.22 & 0 & 15 & 10 & 10 & 5 & 5 & 55 & Forams all ghosts and filled w/ opal; fp 10\% patchy fluids \\
\hline 345 & late Eocene NP $19-20$ & 35.94 & 15.67 & 0 & 15 & 10 & 5 & 5 & 5 & 60 & Forams all ghosts and filled $\mathrm{w} / \mathrm{opal}$; fp $10 \%$ patchy fluids \\
\hline 346 & late Eocene NP 19-20 & 34.73 & 12.92 & 0 & 15 & 15 & 5 & 10 & 5 & 50 & Forams all ghosts and filled w/ opal; fp $10 \%$ patchy fluids \\
\hline 351 & late Eocene NP $19-20$ & 40.31 & 11.53 & 0 & 15 & 15 & 0 & 10 & 0 & 60 & Forams all ghosts and filled w/ opal; fp $10 \%$ patchy fluids \\
\hline 354 & late Eocene NP 19-20 & 46.73 & 9.47 & 0 & 15 & 20 & 0 & 20 & 0 & 45 & Forams all ghosts and filled w/ opal: fn $10 \%$ patchy fluids \\
\hline 356 & late Eocene NP 19-20 & 49.77 & 7.55 & 0 & 10 & 20 & 2 & 5 & 0 & 63 & Forams all ghosts and filled w/ opal; fp 10\% patchy fluids; bigger forams $(.5 \mathrm{~mm})$ \\
\hline 361 & late Eocene NP 19-20 & 48.41 & 10.43 & 0 & 10 & 10 & 0 & 5 & 0 & 75 & Forams all ghosts and filled w/ opal; fp $20 \%$ patchy fluids \\
\hline 363 & late Eocene NP 19-20 & 42.16 & 13.1 & 0 & 10 & 10 & 5 & 5 & 5 & 65 & Forams all ghosts and filled $\mathrm{w} / \mathrm{opal}$; $\mathrm{fp} 20 \%$ patchy fluids \\
\hline 366 & late Eocene NP 19-20 & 44.82 & 11.12 & 0 & 15 & 10 & 2 & 10 & 0 & 63 & Forams all ghosts and filled w/ opal; fp $20 \%$ patchy fluids \\
\hline 369 & late Eocene NP 19-20 & 35.40 & 13.21 & 0 & 10 & 10 & 2 & 10 & 3 & 65 & Forams all ghosts and filled w/ opal; fp $20 \%$ patchy fluids \\
\hline 372 & late Eocene NP 19-20 & 43.00 & 15.12 & 0 & 10 & 10 & 2 & 10 & 0 & 68 & Forams all ghosts and filled w/ opal; fp $20 \%$ \\
\hline 375 & late Eocene NP 19-20 & 42.29 & 8.97 & 0 & 10 & 10 & 5 & 10 & 2 & 63 & Forams all ghosts and filled w/ opal; fp $20 \%$ \\
\hline 378 & late Eocene NP 19-20 & 43.90 & 9.91 & 0 & 15 & 15 & 5 & 10 & 5 & 50 & Forams all ghosts and filled w/ opal; fp $20 \%$ \\
\hline 381 & late Eocene NP 19-20 & 42.78 & 10.72 & 0 & 15 & 20 & 5 & 10 & 5 & 45 & Forams all ghosts and filled w/ opal; fp $20 \%$ \\
\hline 385 & late Eocene NP 19-20 & 42.02 & 10.9 & 0 & 15 & 20 & 2 & 10 & 2 & 51 & Forams all ghosts and filled w/ opal and sparite; fp 30\% \\
\hline 388 & late Eocene NP 19-20 & 41.66 & 8.71 & 0 & 10 & 20 & 5 & 10 & 5 & 50 & Forams all ghosts and filled w/ opal; fp 30\% \\
\hline 391 & late Eocene NP 19-20 & 37.91 & 10.85 & 0 & 10 & 20 & $\begin{array}{c}0 \\
0\end{array}$ & 10 & $\begin{array}{l}3 \\
0\end{array}$ & 75 & $\begin{array}{l}\text { Patchy matrix? fp } 10 \% \\
\text { Palled W/ opal; Ip } 30 \% \\
\end{array}$ \\
\hline 395 & late Eocene NP 19-20 & 43.29 & 12.34 & 0 & 10 & 5 & 2 & 10 & 5 & 68 & Patchy fp. $20 \%$-detrital qtz-forams ghosts or filled w/ opal \\
\hline 398 & late Eocene NP 19-20 & 45.88 & 10.12 & 0 & 10 & 5 & 2 & 10 & 5 & 68 & Patchy fp 20\%-detrital qtz-forams ghosts \\
\hline 401 & late Eocene NP 19-20 & 39.98 & 12.82 & 0 & 10 & 5 & 5 & 10 & 10 & 60 & Patchy fp $20 \%$-detrital qtz-forams ghosts \\
\hline 405 & late Eocene NP 19-20 & 32.8 & 11.81 & 0 & 10 & 5 & 2 & 10 & 5 & 68 & Patchy fp $20 \%$-detrital qtz-forams ghosts \\
\hline 408 & late Eocene NP 19-20 & 33.26 & 15.71 & 0 & 15 & 5 & 0 & 10 & 2 & 68 & Patchy fp 20\%-detrital qtz-forams ghosts \\
\hline 411 & late Eocene NP 19-20 & 34.14 & 19.29 & 0 & 10 & 5 & 0 & 15 & 0 & 70 & Forams: well prssvd, filled w/opal; fp $40 \%$ - forams ghosts; reworked? \\
\hline 414 & late Eocene NP 19-20 & 34.59 & 16.44 & 0 & 10 & 5 & 0 & 20 & 0 & 65 & Forams: well prsrvd, filled w/opal; fp $60 \%$ - forams ghosts; reworked? \\
\hline 416.85 & late Eocene NP 19-20 & 37.52 & 11.01 & 0 & 15 & 15 & 0 & 15 & 0 & 65 & Forams: well prsrvd, filled w/opal and sparite; fp $50 \%$ - nothing unusual-reworked? \\
\hline 417.04 & late Eocene NP 19-20 & 42.94 & 8.63 & 0 & 10 & 15 & 0 & 15 & 0 & 60 & Forams: well prsrvd, filled w/opal, and sparite; fp $10 \%$ - reworked? \\
\hline 417.07 & late Eocene NP $19-20$ & 48.21 & NM & 0 & 15 & 15 & 0 & 10 & 0 & 60 & Forams: well prssrvd, filled w/opal, and sparite; fp $10 \%$ - pocket of forams-reworked? \\
\hline 418 & late Eocene NP 19-20 & 53.94 & 10.65 & 0 & 10 & 10 & 2 & 10 & 0 & 68 & Forams: well prsrvd forms, filled w/opal, fp $10 \%$ \\
\hline 423 & late Eocene NP 18 & 48.60 & 19.03 & 0 & 10 & 10 & 1 & 10 & 0 & $\begin{array}{l}08 \\
69\end{array}$ & 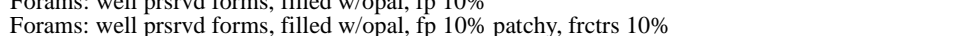 \\
\hline 423.7 & m.m. Eocene NP 16 & 48.66 & 20.05 & 2 & 15 & 15 & 0 & $\begin{array}{r}10 \\
8\end{array}$ & 0 & $\begin{array}{l}09 \\
60\end{array}$ & Forams: well prsrvd, filled w/opal, sparite, dolo; fp10\%- pocket of forams - reworked? \\
\hline 427 & m.m. Eocene NP 16 & 39.85 & 23.09 & 0 & 15 & 5 & 0 & 5 & 0 & 75 & Forams: well prsrvd, filled w/opal, and sparite; fp $10 \%$ \\
\hline 430 & m.m. Eocene NP 16 & 34.36 & 28.49 & 2 & 15 & 8 & 0 & 10 & 0 & 65 & Forams: well prsrvd, filled w/opal, dolo, and sparite; no fp or fretrs \\
\hline 433 & m.m. Eocene NP 16 & 46.96 & 15.56 & 0 & 15 & $\begin{array}{l}\circ \\
5\end{array}$ & 0 & 5 & 0 & 75 & Forams: well prsrvd, filled w/opal and sparite; no fp or fretrs \\
\hline 436 & m.m. Eocene NP 16 & 43.48 & 16.86 & 0 & 15 & 5 & 0 & 5 & 0 & 75 & Forams: well prssvd, filled w/opal and sparite; no fp or frctrs \\
\hline $\begin{array}{l}430 \\
439\end{array}$ & m.m. Eocene NP 16 & $\begin{array}{l}43.48 \\
41.20\end{array}$ & $\begin{array}{l}10.80 \\
16.13\end{array}$ & 0 & 10 & 5 & 0 & 10 & 0 & 75 & $\begin{array}{l}\text { Forams: well prsrvd, filled w/opal and sparite; } 40 \% \text { fp rich in calc. frctrs } 10 \% \text { within fp-possible } \\
\text { iron carb. }\end{array}$ \\
\hline 443 & m.m. Eocene NP 16 & 49.54 & 18.43 & 0 & 10 & 10 & 0 & 5 & 0 & 75 & Forams: well prsrvd, filled w/opal and sparite; $40 \% \mathrm{fp}$ rich in calc. frctrs $10 \%$ within $\mathrm{fp}$ \\
\hline 446 & m.m. Eocene NP 16 & 48.40 & 21.13 & 2 & 10 & 5 & 0 & 3 & 0 & 80 & $\begin{array}{l}\text { Forams: well prsrvd, filled w/sparry calcite opal, and dolo; rad ghosts; } 20 \% \text { fp rich in calc. fretrs } \\
10 \% \text { within fp }\end{array}$ \\
\hline 449 & m.m. Eocene NP 16 & 47.94 & 22.81 & 2 & 15 & 5 & 0 & 3 & 0 & 75 & Forams: well prsrvd, filled w/opal, and dolo; rad ghosts; no fp or frctrs. \\
\hline 452 & m.m.EoceneceneNP15-16 & 47.37 & 15.12 & 2 & 15 & 10 & 0 & 3 & 0 & 70 & Forams: well prsrvd, filled w/sparite, dolo, and opal; rad ghosts; $10 \%$ fp rich in calcite; fretrs $5 \%$. \\
\hline 458 & m.m.EoceneceneNP15-16 & 52.45 & 21.3 & 5 & 10 & 20 & 0 & 5 & 0 & 60 & Forams: well prsrvd, filled w/sparite, dolo, and opal; rad ghosts; $10 \%$ fp rich in calcite; frctrs $5 \%$. \\
\hline 461 & m.m.EoceneceneNP15-16 & 64.89 & 11.69 & 5 & 10 & 20 & 0 & 5 & 0 & 60 & Forams: well prsrvd, filled w/sparite, dolo, and opal; rad ghosts; $20 \%$ fp rich in calcite. \\
\hline 462 & m.m.EoceneceneNP15-16 & 44.67 & 13.66 & 5 & 15 & 15 & 0 & 5 & 0 & 60 & Forams: well prsrvd, filled w/dolo, opal, and sparite; rad ghosts; $10 \% \mathrm{fp}$. \\
\hline 468 & m.m.EoceneceneNP15-16 & 45.54 & 16.43 & 10 & 15 & 15 & 0 & 10 & 0 & 50 & Forams: well prssvd, filled w/dolo, opal, and sparite; rad ghosts; $30 \%$ fp- $10 \%$ frcts. \\
\hline $\begin{array}{l}408 \\
469\end{array}$ & $\begin{array}{l}\text { m.m.EoceneceneNP15-16 } \\
\text { m.m.Eocen }\end{array}$ & 38.03 & 21.17 & 1 & 15 & 10 & 0 & 4 & 0 & 70 & Forams: well prsrvd, most filled w/opal, rad ghosts; $30 \%$ frets. within fp. \\
\hline 409 & $\begin{array}{l}\text { m.m.EoceneceneNPP15-10 } \\
\text { m.m.EoceneceneNP15-16 }\end{array}$ & 44.69 & 17.93 & 0 & 15 & 10 & 0 & $\begin{array}{l}4 \\
5\end{array}$ & 0 & 70 & Forams: well prsrvd, most filled w/opal, no fp, rads ghosts. \\
\hline 475 & m.m.EoceneceneNP15-16 & 45.82 & 20.68 & 0 & 10 & 1 & 0 & 5 & 0 & 75 & Forams: well prsrvd, uniaxial cross, most filled w/opal, few w/ sparite; fp 10\%-rads.ghosts. \\
\hline 478 & ene NP15 & 44.74 & 19.26 & 0 & 10 & 10 & 0 & 5 & 0 & 75 & Forams: well prsrvd, uniaxial cross, most filled w/opal, few w/ sparite; fp $10 \%$, rads ghosts. \\
\hline 483 & m.m.Eocenecene NP15 & 55.91 & 18.81 & 0 & 5 & 10 & 0 & 10 & 0 & 75 & Forams: well prsrvd, most filled w/ sparry calc. few w/opal, fp 20\%, rads ghosts; opaques \\
\hline 486 & m.m.Eocenecene NP15 & 49.51 & 19.84 & 0 & 10 & 5 & 0 & 5 & 0 & 80 & Forams: well prsrvd, uniaxial cross, few filled w/sparite and opal, fp $10 \%$, diatom ghosts. \\
\hline 489 & m.m.Eocenecene NP15 & 42.47 & 21.47 & 0 & 10 & 5 & 0 & 5 & 0 & 80 & $\begin{array}{l}\text { ss, few filled w/opal, fp } 10 \% \text {, diatom ghosts? } \\
\end{array}$ \\
\hline 490 & m.m.Eocenecene NP15 & 47.37 & 20.5 & 0 & 10 & 10 & 0 & 5 & 0 & 75 & $\begin{array}{l}\text { ifilled with opal; frctrs } 10 \% \text {; tp } 10 \% \text {. } \\
\text { Forams: well prsryd, uniaxial cross, most filled w/opal, fp \& frcts } 10 \% \text {, diatom/rads ghosts? }\end{array}$ \\
\hline 496 & m.m.Eocenecene NP15 & 59.76 & 14.74 & 0 & 0 & 10 & 0 & 5 & 0 & 85 & Forams: well prsrvd, recrystallized to sparry calc.; few w/opal, fp \& frcts $10 \%$, diatom ghosts? \\
\hline 503 & n.Eoc & 52.0 & 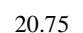 & 0 & 10 & 5 & 0 & 5 & 0 & 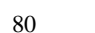 & $\begin{array}{l}\text { filled with op } \\
\text { Forams: well pr }\end{array}$ \\
\hline 510 & & & 20 & 0 & 10 & 5 & 0 & 5 & 0 & o & al. \\
\hline 513 & & & & 0 & 16 & 5 & 0 & 5 & 0 & 8 & \\
\hline 516 & $\mathrm{~m}$ & 44. & 18.98 & 0 & 10 ? & 5 & 0 & 5 & 0 & 8 & Forams: well prsrvd, some uniaxial cross some filled \\
\hline 520 & m.m.Eocenecene NP15b & 46.55 & 20.8 & 0 & 10 ? & 5 & 0 & 10 & 0 & 75 & Forams: well prsrvd, some uniaxial cross some filled w/opal, no fp, diatom ghosts? filled with opal \\
\hline 523 & m.m.Eocenecene NP15b & 51.23 & 16.6 & 0 & & 10 & 0 & 5 & 0 & 85 & Forams: well prsrvd, some uniaxial cross some filled w/opal, no fp \\
\hline
\end{tabular}




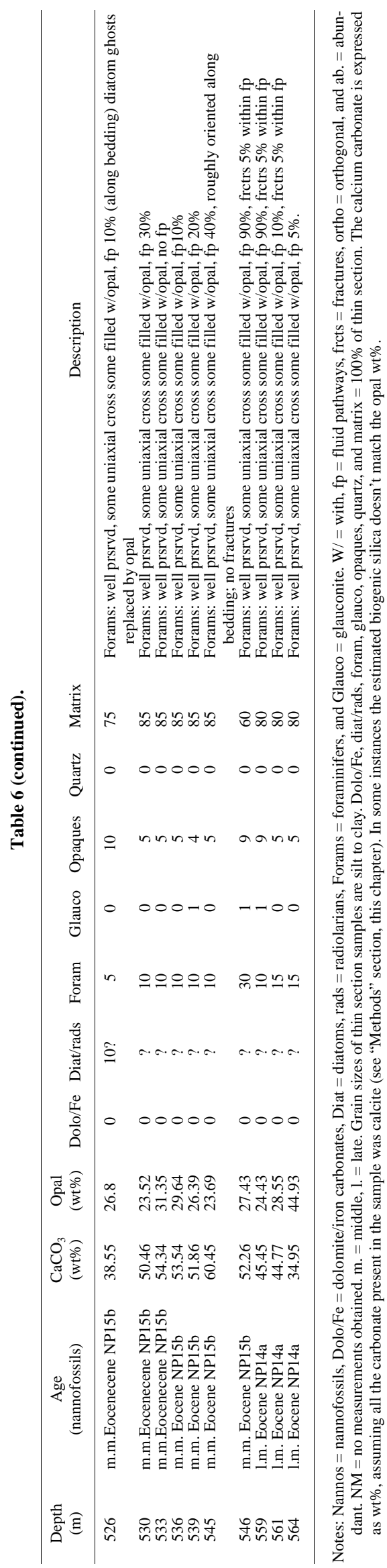

sponse to the changing character of the fluids and surficial sediment. Sediment progradation, that increased in the middle Oligocene and contributed to the transport of terrigenous sediment further offshore, has been correlated to a global $\delta^{18} \mathrm{O}$ increase and a regional cooling, to a long-term sea level lowering, and to possible tectonics (Miller et al., 1996b). These observations suggest that large-scale, diagenetic changes in deep sea slope sediment occur in response to long-term, margin-wide events such as the Oligocene eustatic lowerings.

\section{Sediment Associated with the Ejecta Layer}

Sediment reworking and diagenetic transformations are associated with the interval of correlative age to the ejecta layer at the Atlantic City borehole section (1352-1390 ft [412.2-423.8 m]). Evidence that fluids were more active is noted at $\sim 1354 \mathrm{ft}(412.8 \mathrm{~m})$ where the sediment is marked by a dark stained matrix, patchy cementation, intraclasts, broken foraminiferal tests, glauconites replaced by silica, and abundant pyrite and detrital minerals.

At the slope Sites 903 and 904, abundant fluid pathways and an increase in quartz, glauconite, pyrite, and opal content of the sediment occur immediately above the ejecta layer $(20-100 \mathrm{~cm})$. These observations suggest that mineralogical and diagenetic changes associated with the ejecta were minor at the slope. The occurrence of reworked middle Eocene foraminifers in upper Eocene sediment at all slope sites, including Site 904 where the reworked foraminifers extend for $21 \mathrm{~m}$ above the ejecta layer, suggests that a middle Eocene source of sediment was exposed upslope. The middle Eocene foraminiferal sources have been related to slope failures associated with the late Eocene Chesapeake Bay impact event (McHugh et al., 1996b).

\section{CONCLUSIONS}

Numerous episodes of carbonate diagenesis are recorded in the coastal plain sediment. These types of transformations are typical of the near-shore and near-surface environment where pore fluids are more active. Pore-fluid activity decreases offshore towards the middle slope at Site 904 where cementation is patchy; some microfossils still maintain their primary tests and microfractures are not mineralized. Deep-burial conditions and more extensive diagenetic reactions than at Site 904 are manifested in the sediment at upper slope Sites 903 and 902 where coarsely crystalline ferroan carbonates are common. Silica diagenesis at the slope sites shows a progression with depth of burial from weakly silicified chalks to strongly silicified calcareous porcellanites that contain microfractures. In contrast, coastal-plain silica diagenesis has been influenced by less opal content and an abundance of clay and detrital minerals, and does not show the features that are typical of the slope sediment such as extensive microfracturing.

Sediment adjacent to the uppermost middle Eocene and the lower/ middle Eocene slope unconformities indicate that sediment reworking was minor, but that the diagenetic transformations were extensive. The source of the fluids appears to be local from within the Eocene, and the cementation of the sediment associated with these unconformable surfaces indicates that pore fluids were more active near the unconformities. Lithological and cementation changes are most evident at the unconformable surface between the upper Eocene and the upper Oligocene where sediment beneath the unconformity recorded extensive diagenetic alterations. These observations suggest that diagenetic transformations in the slope sediment are to a great extent influenced by large-scale sedimentation changes in the margin such as the switch from Eocene pelagic carbonate to Oligocene hemipelagic siliciclastic sediments. The more accentuated sea-level lowerings that occurred in response to global cooling and possible tectonics (Miller et al., 1996b) from the early Eocene to the Oligocene contributed to the changes in mineral content, fluid character, and diagenetic transformations at the slope sites. 


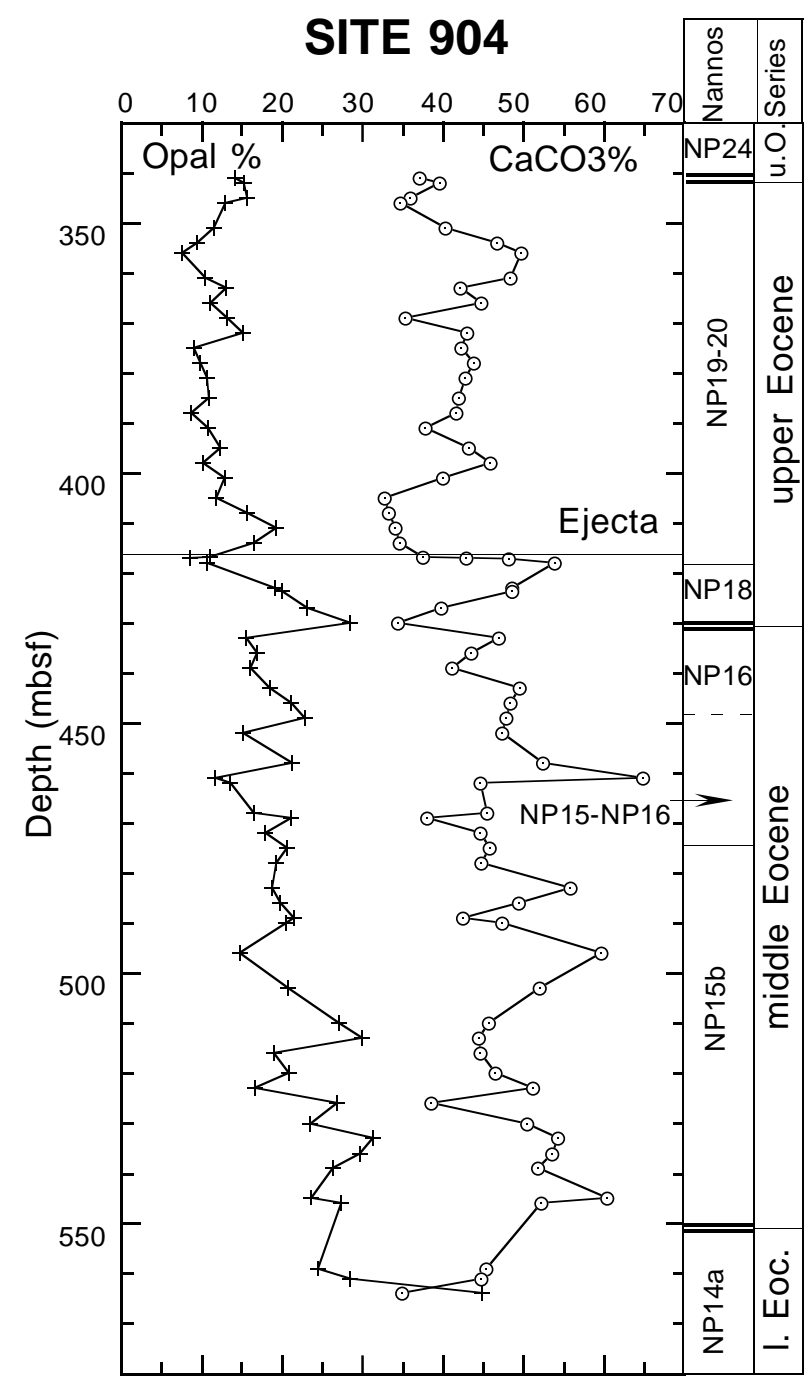

Figure 7. Biogenic opal and calcium carbonate content vs. depth for Site 904, showing the biostratigraphic nannoplankton zones and age of three unconformities (double lines). Note ejecta layer at $415.8 \mathrm{mbsf} . \mathrm{m}=\mathrm{mbsf}$.

\section{ACKNOWLEDGMENTS}

I would like to thank K.G. Miller for making this study possible and J.V. Browning for his contributions to the sampling and interpretation of the data. I also would like to acknowledge Lenny Canone from Queens College who prepared the petrographic thin sections and Dee Breger from LDEO. Reviews by Ken Miller, Jim Browning, and an anonymous reviewer helped to improved the manuscript.

This study was supported by a P.S.- C.U.N.Y.Grant No. 666214. This is a Lamont-Doherty Earth Observatory contribution number 5552 .

\section{REFERENCES}

Aubry, M.-P., Snyder, S.W., Van Fossen, M.C., Urbat, M., Katz, M.E., Miller, K.G., and McHugh, C.M.G., 1996. Stratigraphy of the Eocene chalks recovered from the New Jersey Margin, Leg 150: synthesis. In Mountain, G.S., Miller, K.G., Blum, P., Poag, C.W., and Twichell, D.C. (Eds.), Proc. ODP, Sci. Results, 150: College Station, TX (Ocean Drilling Program), 429-432.

Bathurst, R.G.C., 1975. Carbonate Sediments and Their Diagenesis (2nd ed.): Amsterdam (Elsevier).
Buddemeier, R.W., and Oberdorfer, J.A., 1986. Internal hydrology and geochemistry of coral reefs and atoll islands: key to diagenetic variations. In Schroeder, J.H., and Purser, B.H. (Eds.), Reef Diagenesis, Berlin (Springer-Verlang), 91-111.

Choquette, P.W., and James, N.P., 1987. Diagenesis of limestones, 3: the deep burial environment. Geosci. Can., 14:3-35.

Glass, B.P., 1989. North American tektite debris and impact ejecta from DSDP Site 612. Meteoritics, 24:209-218.

Glass, B.P., and McHugh, C.M.G., 1996. More upper Eocene (North American?) tektites and impact ejecta off New Jersey. 27th Lunar Planet. Sci. Conf., Houston, Texas, 18-22.

Hinman, N.W., 1990. Chemical factors influencing the rates and sequences of silica phase transitions: effects of organic constituents. Geochim. Cosmochim. Acta, 54:1563-1574.

Isaacs, C.M., 1982. Influence of rock compositions on kinetics of silica phase changes in the Monterey Formation, Santa Barbara area, California. Geology, 10:304-308.

James, N.P., and Choquette, P.W., 1983. Diagenesis 6: Limestones: the seafloor diagenetic environment. Geosci. Can., 10:162-179.

$\longrightarrow$ 1984. Diagenesis 9: Limestones-the meteoritic diagenetic environment. Geosci. Can., 11:161-194.

Jones, J.B., and Segnit, E.R., 1972. Genesis of cristobalite and tridymite at low temperatures. J. Geol. Soc. Aust., 18:419-422.

Kastner, M., 1981. Authigenic silicates in deep sea sediments: formation and diagenesis. In Emiliani, C. (Ed.), The Sea (Vol. 7): The Oceanic Lithosphere: New York (Wiley), 915-980.

Kastner, M., Keene, J.B., and Gieskes, J.M., 1977. Diagenesis of siliceous oozes, I. Chemical controls on the rate of opal-A to opal-CT transformation[0151] an experimental study. Geochim. Cosmochim. Acta, 41:10411059.

Katz, M.E., and Miller, K.G., 1996. Eocene to Miocene oceanographic and provenance changes in a sequence stratigraphic framework: benthic foraminifers of the New Jersey Margin. In Mountain, G.S., Miller, K.G., Blum, P., Poag, C.W., and Twichell, D.C. (Eds.), Proc. ODP, Sci. Results, 150: College Station, TX (Ocean Drilling Program), 65-95.

Margins Steering Committee Members, 1993. MARGINS: toward a Novel Science Plan. Eos, 74:570-572.

McHugh, C.M., 1993. Submarine canyons and deep-sea fan systems of passive and active continental margins [Ph.D. dissert.]. Columbia University, New York.

McHugh, C.M., Ryan, W.B.F., and Schreiber, B.C., 1993. The role of diagenesis in exfoliation of submarine canyons. AAPG Bull., 77:145-172.

McHugh, C.M.G, Damuth, J.E., Gartner, S., Katz, M.E, and Mountain, G.S., 1996a. Oligocene to Holocene mass-transport deposits of the New Jersey continental margin and their correlation to sequence boundaries. In Mountain, G.S., Miller, K.G., Blum, P., Poag, C.W., and Twichell, D.C. (Eds.), Proc. ODP, Sci. Results, 150: College Station, TX (Ocean Drilling Program), 189-228.

McHugh, C.M.G., Snyder, S.W., Deconinck, J.-F, Saito, Y., Katz, M.E., and Aubry, M-P, 1996b. Upper Eocene tektites of the New Jersey Continental Margin, Site 904. In Mountain, GS., Miller, KG., Blum, P., Poag, CW., and Twichell, DC. (Eds.), Proc. ODP, Sci. Results, 150: College Station, TX, (Ocean Drilling Program), 241-265.

Miller K.G., et al., 1994. Proc. ODP, Init. Repts., 150X: College Station, TX, (Ocean Drilling Program).

Miller K.G., et al., 1996a. Proc. ODP, Init. Repts., 150X (Suppl.): College Station, TX, (Ocean Drilling Program).

Miller, K.G., Kent, D.V., Brower, A.N., Bybell, L.M., Feigenson, M.D., Olsson, R.K., and Poore, R.Z., 1990. Eocene-Oligocene sea-level changes on the New Jersey coastal plain linked to the deep-sea record. Geol. Soc. Am. Bull., 102:331-339.

Miller, K.G., Liu, C., and Feigenson, M.D., 1996b. Oligocene to middle Miocene Sr-isotopic stratigraphy of the New Jersey continental slope. In Mountain, G.S., Miller, K.G., Blum, P., Poag, C.W., and Twichell, D.C. (Eds.), Proc. ODP, Sci. Results, 150: College Station, TX, (Ocean Drilling Program), 97-114.

Mortlock, R.A., and Froelich, P.N., 1989. A simple method for the rapid determination of biogenic opal in pelagic marine sediments. Deep-Sea Res. Part A, 36:1415-1426.

Mountain, G.S., Miller, K.G., Blum, P., et al., 1994. Proc. ODP, Init. Repts., 150: College Station, TX (Ocean Drilling Program).

Odin, G.S., and Matter, A., 1981. Die glauconarium origine. Sedimentology, 28:611-643.

Olsson, R.K., and Wise, S.W., 1987. Upper Maestrichtian to middle Eocene stratigraphy of the New Jersey slope and coastal plain. In van Hinte, J.E., 
Wise, S.W., Jr., et al., Init. Repts. DSDP, 93 (Pt. 2): Washington (U.S. Govt. Printing Office), 1343-1365.

Poag, C.W., and Aubry, M.-P., 1995. Upper Eocene impactites of the U.S. coast: depositional origins, biostratigraphic framework, and correlation. Palaios, 10:16-43.

Poag, C.W., Powars, D.S., Poppe, L.J., and Mixon, R.B., 1994. Meteroid mayhem in Ole Virginny: source of the North American tektite strewn field. Geology, 22:691-694.

Poag, C.W., Powars, D.S., Poppe, L.J., Mixon, R.B., Edwards, L.E., Folger, D.W., and Bruce, S., 1992. Deep Sea Drilling Project Site 612 bolide event: new evidence of a late Eocene impact-wave deposit and a possible impact site, U.S. east coast. Geology, 20:771-774.

Poag, C.W., Watts, A.B., et al., 1987. Init. Repts. DSDP, 95: Washington (U.S. Govt. Printing Office).

Poag, C.W., and Low, D., 1987. The New Jersey transect: stratigraphic framework and depositional history of a sediment-rich passive margin. In Poag, C.W., Watts, A.B., et al., Init. Repts. DSDP, 95: Washington (U.S. Govt. Printing Office), 763-817.

Riech, V., and von Rad, U., 1979. Eocene porcellanites and early Cretaceous cherts from the Western North Atlantic. In Tucholke, B.E., Vogt, P.R., et al., Init. Repts. DSDP, 43: Washington (U.S. Govt. Printing Office), 437-448.

Sibley, D.F., 1982. Origin of common dolomite fabrics: clues from the Pliocene. J. Sediment. Petrol., 52:1087-1100.

Sibley, D.F., and Gregg, J.M., 1987. Classification of dolomite rock textures. J. Sediment. Petrol., 57:967-975.

Snyder, S.W., Miller, K.G., and Saperson, E., 1996. Paleogene and Neogene planktonic foraminiferal biostratigraphy of the New Jersey continental slope: Sites 902, 903, and 904. In Mountain, GS., Miller, KG., Blum, P., Poag, CW., and Twichell, DC. (Eds.), Proc. ODP, Sci. Results, 150: College Station, TX (Ocean Drilling Program), 3-15.
Thein, J., 1987. A tektite layer in upper Eocene sediments of the New Jersey continental slope (Site 612, Leg 95). In Poag, C.W., Watts, A.B., et al., Init. Repts. DSDP, 95: Washington (U.S. Govt. Printing Office), 565-579.

Thein, J., and von Rad, U., 1987. Silica diagenesis in continental rise and slope sediments off eastern North America (Sites 603 and 605, Leg 93; Sites 612 and 614, Leg 95). In Poag, C.W., Watts, A.B., et al., Init. Repts. DSDP, 95: Washington (U.S. Govt. Printing Office), 501-525.

Tucholke, B.E., and Mountain, G.S., 1979. Seismic stratigraphy, lithostratigraphy, and paleosedimentation patterns in the North American Basin. In Talwani, M., Hay, W., and Ryan, W.B.F. (Eds.), Deep Drilling Results in the Atlantic Ocean: Continental Margins and Paleoenvironment. Am. Geophys. Union, Maurice Ewing Ser., 3:58-86.

Tucker, M.E., and Wright, P.V., 1990. Carbonate Sedimentology: Oxford (Blackwell Sci. Publ.).

von Rad, U., and Botz, R., 1987. Diagenetic Fe-Mn carbonates in Cretaceous and Tertiary sediments of the continental rise off eastern North America, Deep Sea Drilling Project Site 603. In van Hinte, J.E., Wise, S.W., Jr., et al., Init. Repts. DSDP, 93 (Pt. 2): Washington (U.S. Govt. Printing Office), 1061-1077.

Weaver, F.M., and Wise, S.W., Jr., 1972. Ultramorphology of deep sea cristobalitic chert. Nature, Phys. Sci., 237:56-57.

Wilkens, R.H., Schreiber, B.C., Caruso, L., and Simmons, G., 1987. The effects of diagenesis on the microstructure of Eocene sediments bordering the Baltimore Canyon Trough. In Poag, C.W., Watts, A.B., et al., Init. Repts. DSDP, 95: Washington (U.S. Govt. Printing Office), 527-547.

Date of initial receipt: 26 February 1996

Date of acceptance: 13 September 1996

Ms 150XSR-303 


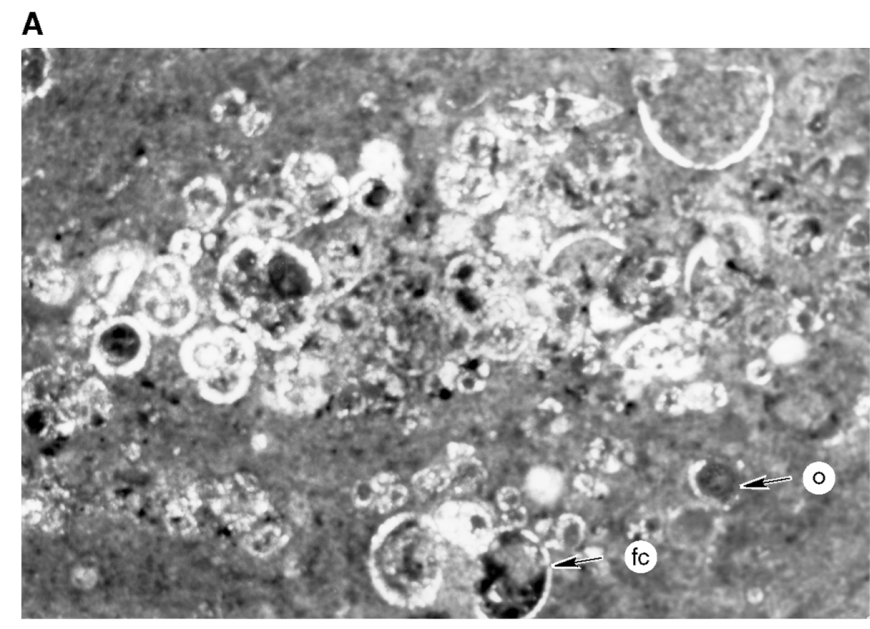

\section{B}

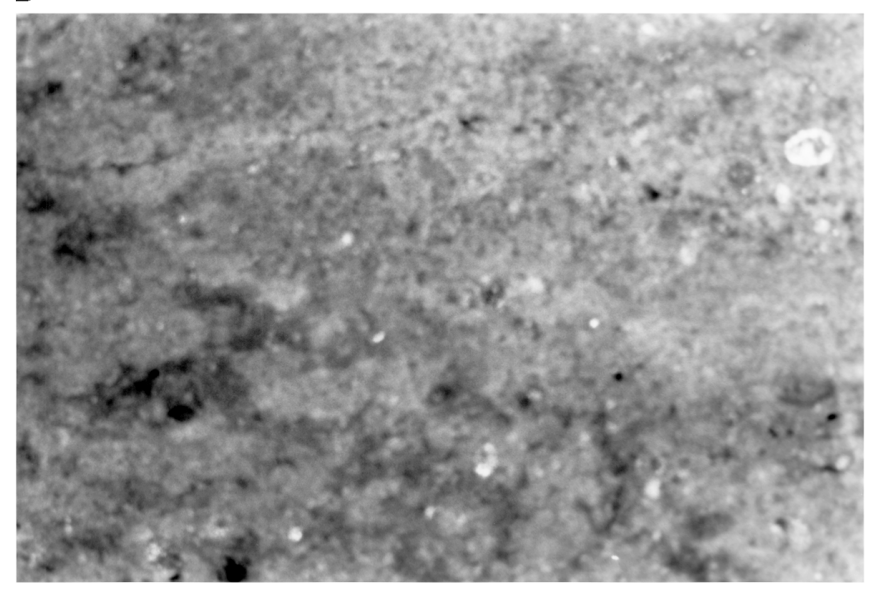

Figure 8. Sediment below middle/upper Eocene unconformity at Site 904. A. Foraminiferal clusters. Tests are filled with opal (o), ferroan carbonates (fc), and pyrite (bar $=1 \mathrm{~mm}$; cross-nicols, $423.7 \mathrm{mbsf}$. B. Minor darkstained patches occur in the matrix (bar $=1 \mathrm{~mm}$; cross-nicols, $423.7 \mathrm{mbsf}$ ).

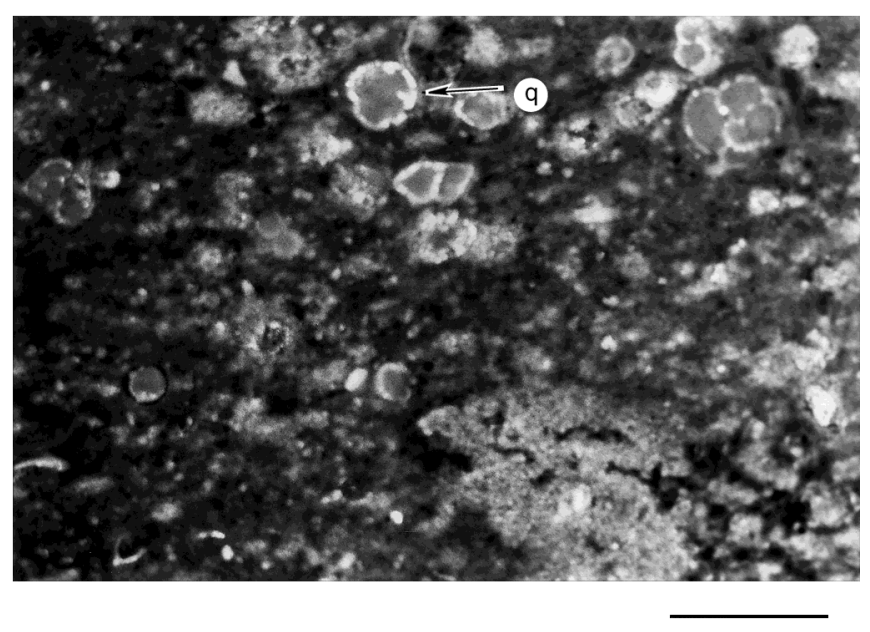

Figure 9. Unconformity between the lower middle Eocene and the middle middle Eocene at Site 904. Sediment above the unconformity is characterized by extensive alteration of foraminiferal tests to quartz (q) and former fluid migration routes. White patches (bottom right of photo) are rich in silica and chloride and stain the matrix (bar = $1 \mathrm{~mm}$; cross-nicols, $546 \mathrm{mbsf}$ ). 


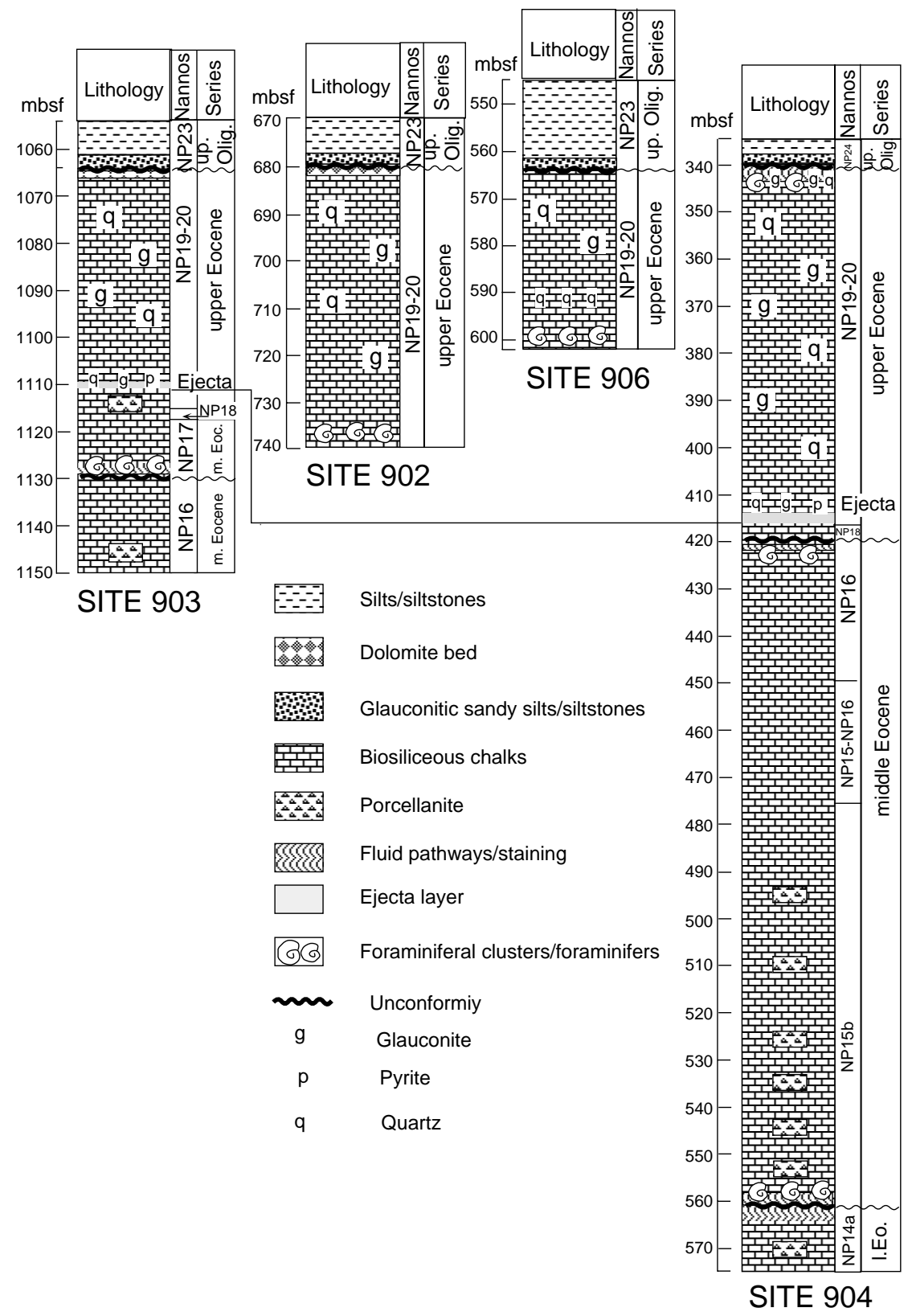

Figure 10. Summary figure showing lithology, age, biostratigraphic nannoplankton zones, and interpretation of sediment above and below unconformities at all slope sites. 

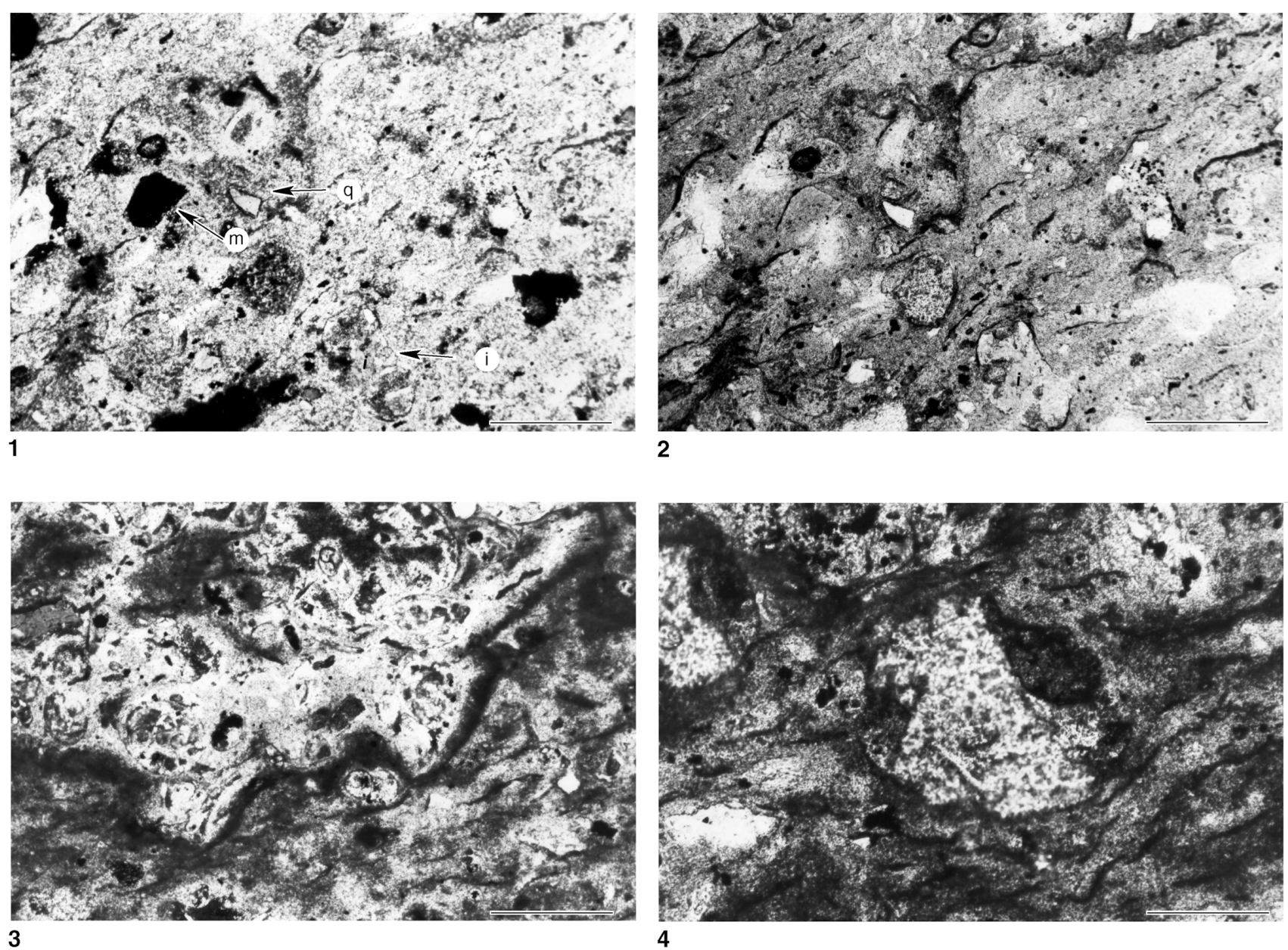

Plate 1. Thin sections of interval with mixed biostratigraphic markers at Atlantic City, $1354 \mathrm{ft}(45 \mathrm{~m})$. 1. Disrupted matrix with isotropic minerals (m), detrital quartz (q), pyrite (p), intraclasts (i), and dark stains (bar $=1 \mathrm{~mm}$; cross-nicols). 2. Same thin section as 1 (plane light). 3. Cluster of broken and altered foraminifers rimmed by dark-stained matrix $(\mathrm{bar}=1 \mathrm{~mm})$. 4. Glauconite grains have undergone extensive alteration. Northeast corner of center grain has been altered to silica (bar $=250 \mu \mathrm{m}$; cross-nicols). 

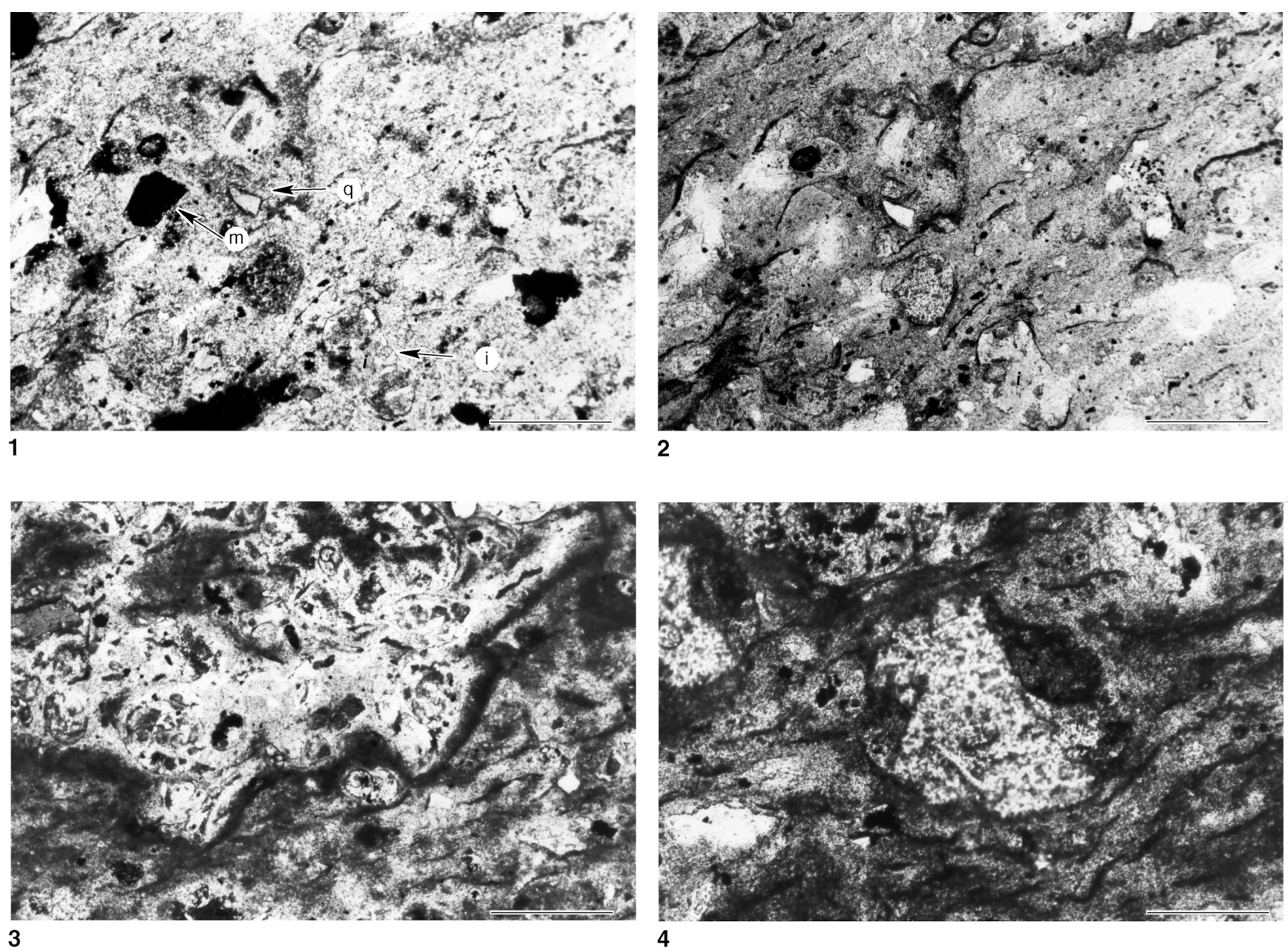

Plate 2. Upper Eocene beneath unconformable surface with the upper Oligocene at Site 903, 1064 mbsf. 1. Thin section (cross-nicols) of idiotopic mosaic of euhedral to subhedral dolomite rhombs. Foraminiferal test filled with large sparry calcite crystal and ferroan dolomite rhombs (dark-stained; bar $=250 \mu \mathrm{m})$. 2. SEM backscatter micrograph shows differences in chemical composition of zoned dolomite rhombs and matrix $($ bar $=20 \mu \mathrm{m}) .3$. EDX analysis of matrix. 4 . EDX analysis of calcium-rich core in dolomite rhomb. 

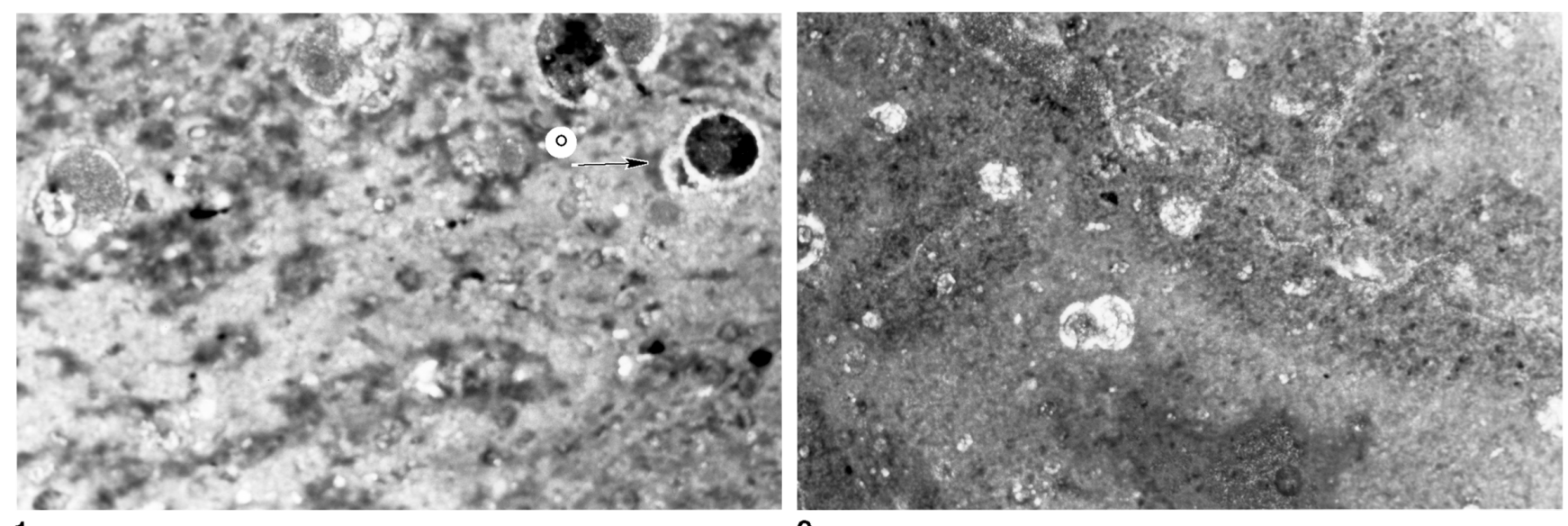

1

$\mu \mathrm{m}$

2

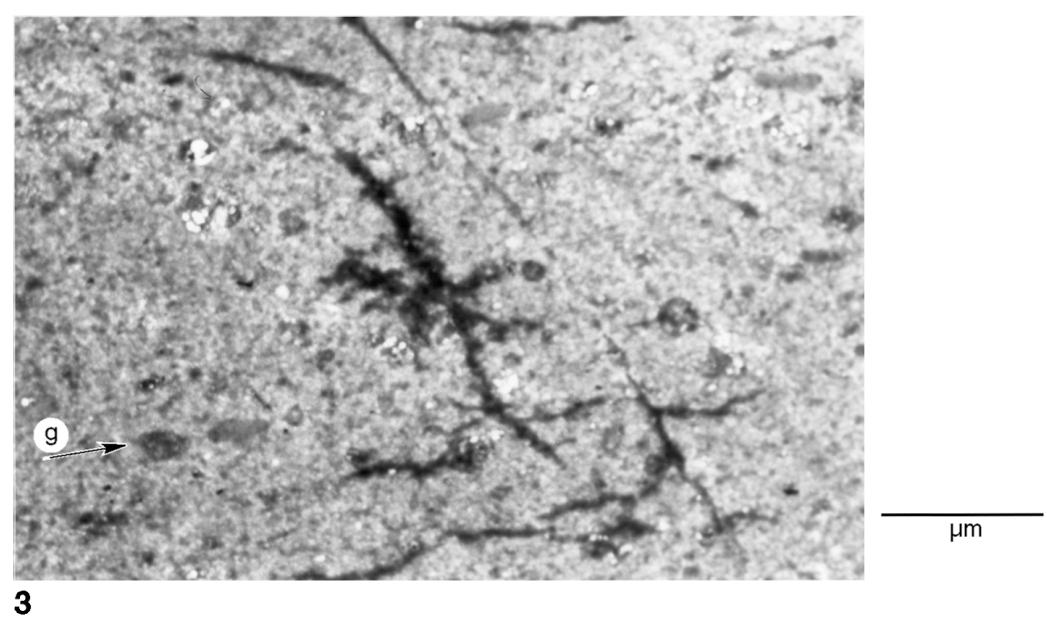

$\mu \mathrm{m}$

\section{3}

Plate 3. Thin sections showing silica diagenesis at Site 904. 1. Upper Eocene foraminiferal tests are well preserved and filled with opal (o). The matrix is commonly stained with light to dark patches (bar $=1 \mathrm{~mm}$; cross-nicols, $356 \mathrm{mbsf}$ ). 2. Middle Eocene foraminifers still maintain their primary cementation (pseudo uniaxial cross). Note fluid pathways and microfractures (bar $=1 \mathrm{~mm}$; cross-nicols, $459 \mathrm{mbsf}$ ). 3. Middle Eocene matrix with silica ghosts ( $\mathrm{g}$ ) and dark-stained former fluid-routes forming orthogonal intersections (bar = $1 \mathrm{~mm}$; cross-nicols, $483 \mathrm{mbsf}$ ). 

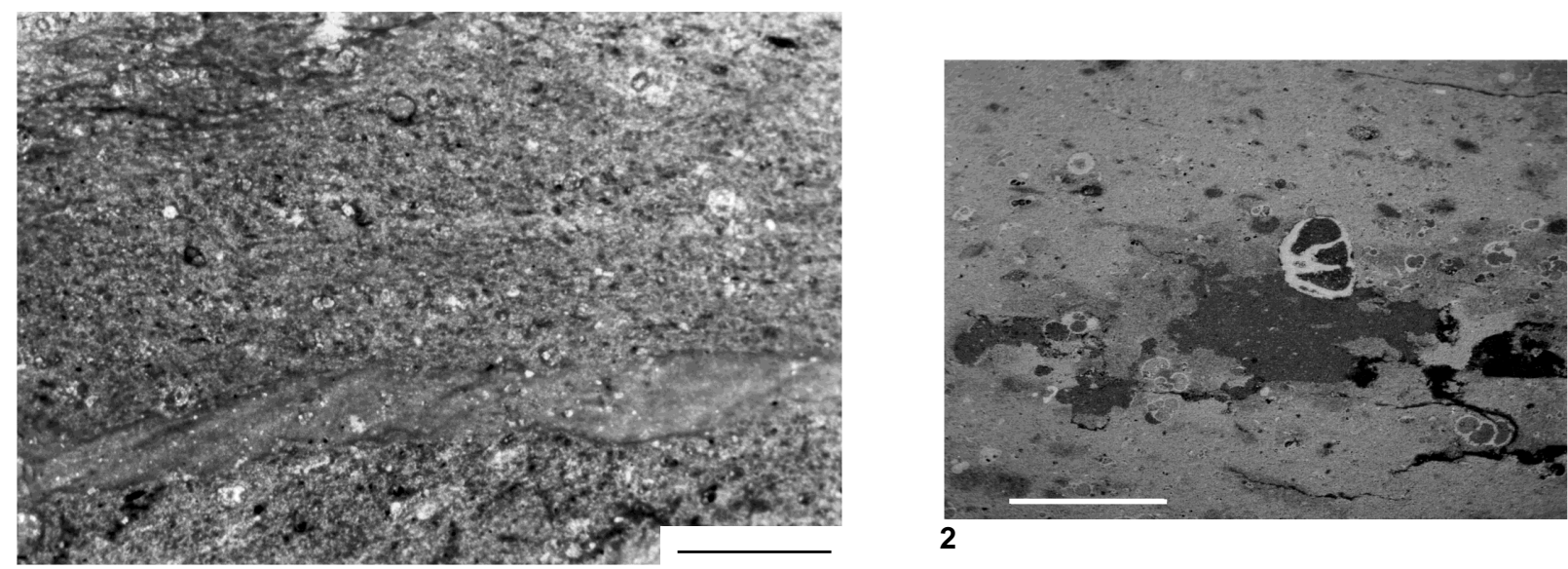

1
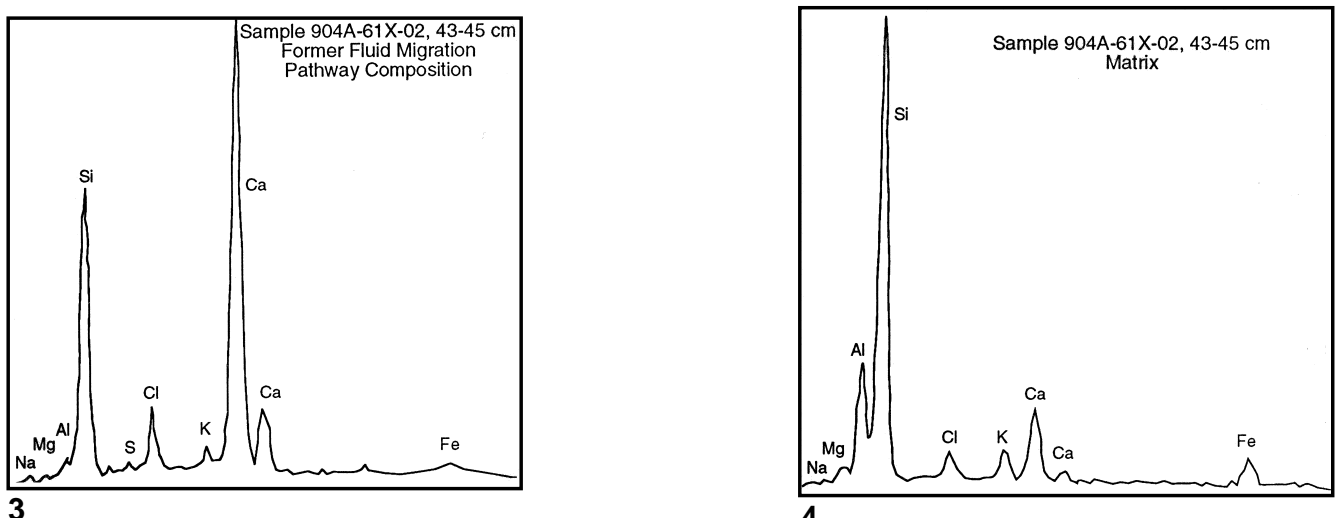

Plate 4. Lower middle Eocene below unconformable surface with middle middle Eocene at Site 904 (559 mbsf). 1. Photomicrograph of matrix with extensive former fluid migration pathways (bar $=1 \mathrm{~mm}$; cross-nicols). 2. SEM backscatter micrograph of former fluid routes (bar $=1 \mathrm{~mm})$. 3. Dark-stained matrix is rich in calcium and silica. 4. Matrix is rich in silica with minor aluminum and calcium. 


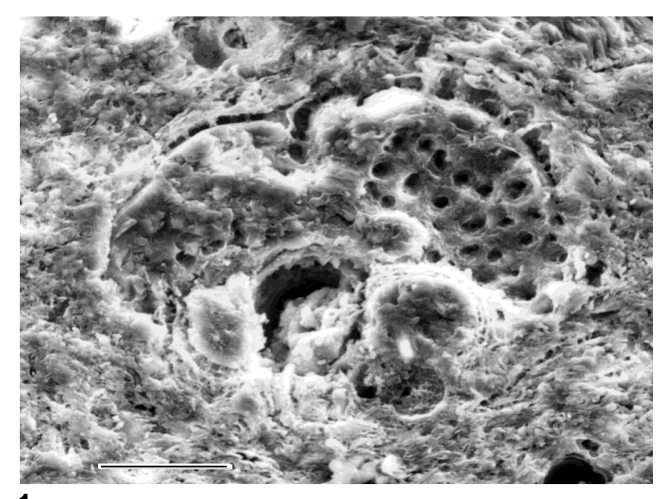

1

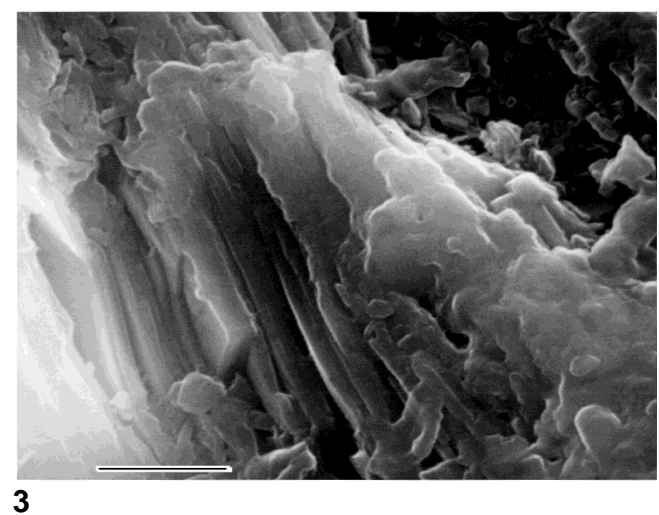

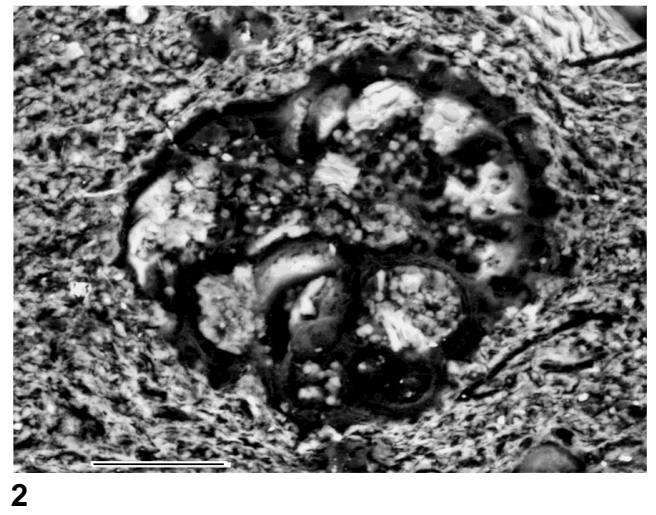

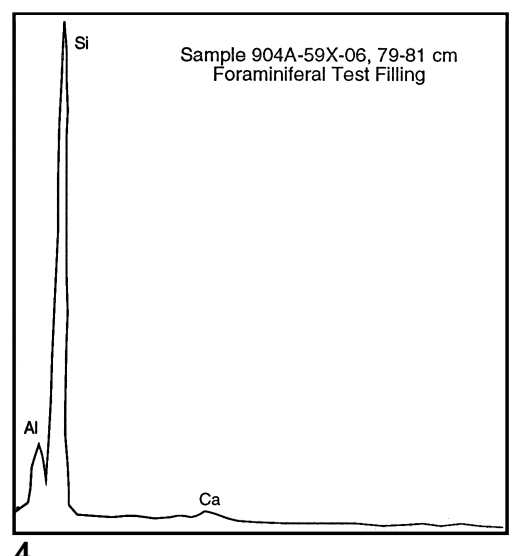

Plate 5. Middle middle Eocene above unconformable surface with lower middle Eocene at Site 904 (546 mbsf). 1. SEM micrograph of altered foraminiferal test $(\mathrm{bar}=40 \mu \mathrm{m})$. 2. SEM micrograph (backscatter) of same foraminiferal test as 1 , showing opal-CT lepispheres and white platy cements $(\mathrm{bar}=40 \mu \mathrm{m}) . \mathbf{3}$. SEM micrograph of white platy cements showing recrystallyzed quartz and kaolinite plates (bar $=1 \mathrm{~mm})$. 4. EDX analysis of white cements. 